\title{
ACIDOPHILOUS DRY GRASSLANDS ON THE QUARTZITE BEDROCK IN WESTERN SLOVAKIA
}

\author{
Daniela DÚBRAVKOVÁ ${ }^{1,2}$ \& Jaroslav KOŠŤÁL ${ }^{3}$
}

\begin{abstract}
The paper presents results of actual phytocoenological research of acidophilous dry grasslands of the KoelerioPhleion phleoidis Korneck 1974 alliance on the quartzite bedrock in western Slovakia. The modified TWINSPAN analysis distinguished two associations in the study area. Avenulo pratensis-Festucetum valesiacae Vicherek et al. in Chytrý et al. 1997 is dominated by Festuca valesiaca s.l. and it is distributed on the quartzite hills in the Tribeč Mts. Potentillo heptaphyllae-Festucetum rupicolae (Klika 1951) Toman 1970 occurs at sites in the Biele Karpaty Mts and Považský Inovec Mts and it is dominated by Festuca rupicola. The paper brings very first data on distribution of Avenulo pratensis-Festucetum valesiacae in Slovakia and extends knowledge on occurrence of Potentillo heptaphyllae-Festucetum rupicolae. Both associations represent very rare vegetation types of Central Europe. In Slovakia, they occur locally at small sized stands and are threatened by successional changes caused by cessation of traditional management and island occurrence within other vegetation types. Main environmental gradients responsible for variation in species composition of these grasslands were revealed by the principal component analysis (PCA) and interpreted using indicator values and measured characteristics of the study sites. The major pattern of variation reflects altitude, which is negatively correlated with temperature and soil depth. The relationship between species composition and environmental factors (pedology, topography, geographical position) was analysed by redundancy analysis (RDA). The most important factor affecting the data variation was longitude followed by soil $\mathrm{pH}$, slope and latitude.

Key words: Biele Karpaty Mts, Koelerio-Phleion phleoidis, Lower and Upper Triassic quartzite, modified TWINSPAN, phytocoenology, Považský Inovec Mts, Tribeč Mts, xerophilous grassland vegetation.

\section{Izvleček}

V članku so predstavljeni rezultati fitocenološke raziskave kisloljubnih suhih travišč zveze Koelerio-Phleion phleoidis Korneck 1974 na kvarcitni matični podlagi na zahodnem Slovaškem. Z modificirano TWINSPAN analizo smo na raziskovanem območju ločili dve asociaciji. V sestojih asociacije Avenulo pratensis-Festucetum valesiacae Vicherek et al. in Chytrý et al. 1997 prevladuje vrsta Festuca valesiaca s.l., ki je razširjena na kvarcitnem hribovju v gorovju Tribeč. Sestoje asociacije Potentillo heptaphyllae-Festucetum rupicolae (Klika 1951) Toman 1970 najdemo v gorovjih Biele Karpaty in Považský Inovec in v njih prevladuje vrsta Festuca rupicola. V članku se prvič omenja pojavljanje asociacije Avenulo pratensis-Festucetum valesiacae na Slovaškem, ki razširja poznavanje razširjenosti asociacije Potentillo heptaphyllae-Festucetum rupicolae. Obe asociaciji predstavljata redke vegetacijske tipe v srednji Evropi. Na Slovaškem se pojavljata lokalno na majhnih površinah in sta ogroženi s sukcesijskimi spremembami zaradi opuščanja tradicionalnega gospodarjenja in zaradi izoliranega pojavljanja znotraj drugih vegetacijskih tipov. Glavne ekološke gradiente, ki so odgovorni za variabilnost vrstne sestave travišč, smo dobili z uporabo metode glavnih komponent (PCA) in jih ovrednotili z indikatorskimi in merjenimi vrednostmi. Glavni vzorec variabilnosti se odraža zaradi nadmorske višine, ki je v negativni korelaciji s temperaturo in globino tal. Povezavo med vrstno sestavo in okoljskimi dejavniki (pedologijo, topografijo, geografskim položajem) smo analizirali z analizo presežkov (RDA). Najpomembnejši dejavnik je bila geografska dolžina, ki ji sledijo $\mathrm{pH}$ tal, naklon in geografska širina.

Ključne besede: gorovje Biele Karpaty, Koelerio-Phleion phleoidis, spodnji in zgornji triasni kvarcit, modificirana TWINSPAN metoda, fitocenologija, gorovje Považský Inovec Mts, Tribeč, kserofilna travniška vegetacija.

\footnotetext{
${ }^{1}$ Institute of Botany, Slovak Academy of Sciences, Dúbravská cesta 9, SK-845 23 Bratislava, Slovakia

${ }^{2}$ Homeland Museum in Považská Bystrica, Ul. odborov 244/8, SK-017 01 Považská Bystrica, Slovakia; daniela.dubravkova@savba.sk

${ }^{3}$ State Nature Conservancy of the Slovak Republik, Administration of Protected Landscape Area Ponitrie, Samova 3 , SK-949 01 Nitra, Slovakia; kostaljar@gmail.com
} 


\section{INTRODUCTION}

The Central European acidophilous dry grasslands are conventionally classified within the Koelerio-Phleion phleoidis Korneck 1974 alliance (Festuco-Brometea Br.-Bl. et Tüxen ex Soó 1947) in the syntaxonomical classification system (Korneck 1974, Dúbravková et al. 2010). These communities are distributed mostly in France, southern Germany, Austria and the Czech Republic (Chytrý et al. 1997). Some localities of acidophilous dry grasslands also occur in western Slovakia (located in eastern part of Central Europe) where they represent a rare vegetation type. These grasslands developed on the shallow rocky soils over acidic silicate rocks such as granite, gneiss, crystalline shale, quartzite, etc. These bedrock types are rather scarce in the territory of Slovakia. Besides the western Slovakia the shallow acidic rocky soils are locally distributed in other parts of the country as well, however various types of vegetation other than dry grasslands mostly cover the stands.

The literature sources deal with the acidophilous dry grasslands in Slovakia only sporadically. Chytrý et al. (1997) and Zlinská (2000) documented the vegetation of Potentillo heptaphyllae-Festucetum rupicolae (Klika 1951) Toman 1970 (syn. Astero linosyris-Festucetum rupicolae Maglocký in Chytrý et al. 1997 and Peucedano oreoselini-Festucetum rupicolae Vicherek et al. in Chytrý et al. 1997) at granite bedrock at the southeastern slopes of the Malé Karpaty Mts between Bratislava and Vinosady and at the acidic Pleistocene sands in the Borská nížina Lowland near Závod. These localities were considered as the only sites of the Koelerio-Phleion phleoidis in Slovakia in the past (Michálková 2007). However, our field research proved that the acidophilous dry grasslands in Slovakia occur in larger extends than formerly expected. Since the dry grassland vegetation on acidic bedrocks types other than granite and sands has so far been neglected in the phytosociological literature we aim to fill this gap focussing particularly on the dry grassland stands on the quartzite bedrock. We (1) present new vegetation data of the acidophilous dry grasslands on quartzite in the Tribeč Mts, Považský Inovec Mts and Biele Karpaty Mts in western Slovakia; (2) perform a numerical classification of the data and assign the clusters to associations described in the phytosociological literature; and (3) evaluate the environmental characteristics of the distinguished associations.

\section{MATERIAL AND METHODS}

\subsection{Quartzite Bedrock ANd Study area}

The Lower Triassic quartzite is one of the most acidic silicate rock types. It is very poor in minerals; the crystalline quartzite contains only a trace amount of $\mathrm{CaO}$, the amount of $\mathrm{MgO}$ varies in insignificant values, while $\mathrm{K}_{2} \mathrm{O}$ and $\mathrm{P}_{2} \mathrm{O}_{5}$ are missing completely (Húsenica 1964). The quartzite bedrock in Slovakia occurs most frequently at the edges of the Tribec Mts as the remnants of the Mesozoic (Lower Triassic) shell cover of the crystalline mountains. Here the quartzite bedrock creates typical small quartzite hills with rocky hilltops (Mederly \& Hreško 1988). In these stands, various types of acidophilous vegetation occur, such as pioneer, scree and grassland communities or shrubby and forest vegetation (Eliáš 1986). In a small extent the quartzite is also distributed in the Považský Inovec Mts, Biele Karpaty Mts, Malé Karpaty Mts, Revúcka vrchovina Upland, Turčianska kotlina Basin, Lučenecká kotlina Basin and in a few other small localities in the Western Carpathian Mts.

The dry grasslands presented in current paper are located in the Tribeč Mts, Považský Inovec Mts and Biele Karpaty Mts. The three mountain ranges are located at the western edges of the Carpathian Mountain Arch. They represent the southwestern foothills of the Western Carpathians (the phytogeographical unit of PreaCarpathicum) and are in direct contact with the thermophilous flora of the Pannonian region (Pannonicum, Futák 1980). The study area is located in the warm climatic region. The everage annual air temperature reaches $8-9{ }^{\circ} \mathrm{C}$ and everage annual precipitation 600-700 $\mathrm{mm}$ (Lapin et al. 2002, Štastný et al. 2002, Faško \& Št́astný 2002a).

The Tribeč Mts and Považský Inovec Mts are the crystalline Central Western Carpathian mountain ranges that are built of the granite central core and the outer Mesozoic sedimentary rocks (e.g. limestone, dolomites and quartzite) that usually occur at the margins of the mountain ranges. The localities of acidophilous dry grasslands in the Tribeč Mts and Považský Inovec Mts occur at the sites of Lower Triassic quartzite. The Biele Karpaty Mts are a part of the Outer Western Carpathians and formed mostly of flysch rocks (e.g. sandstone, claystone, shale and conglomerate). The quartzite at the dry grassland localities Skalický vrch and Ostrá hôrka is of the 


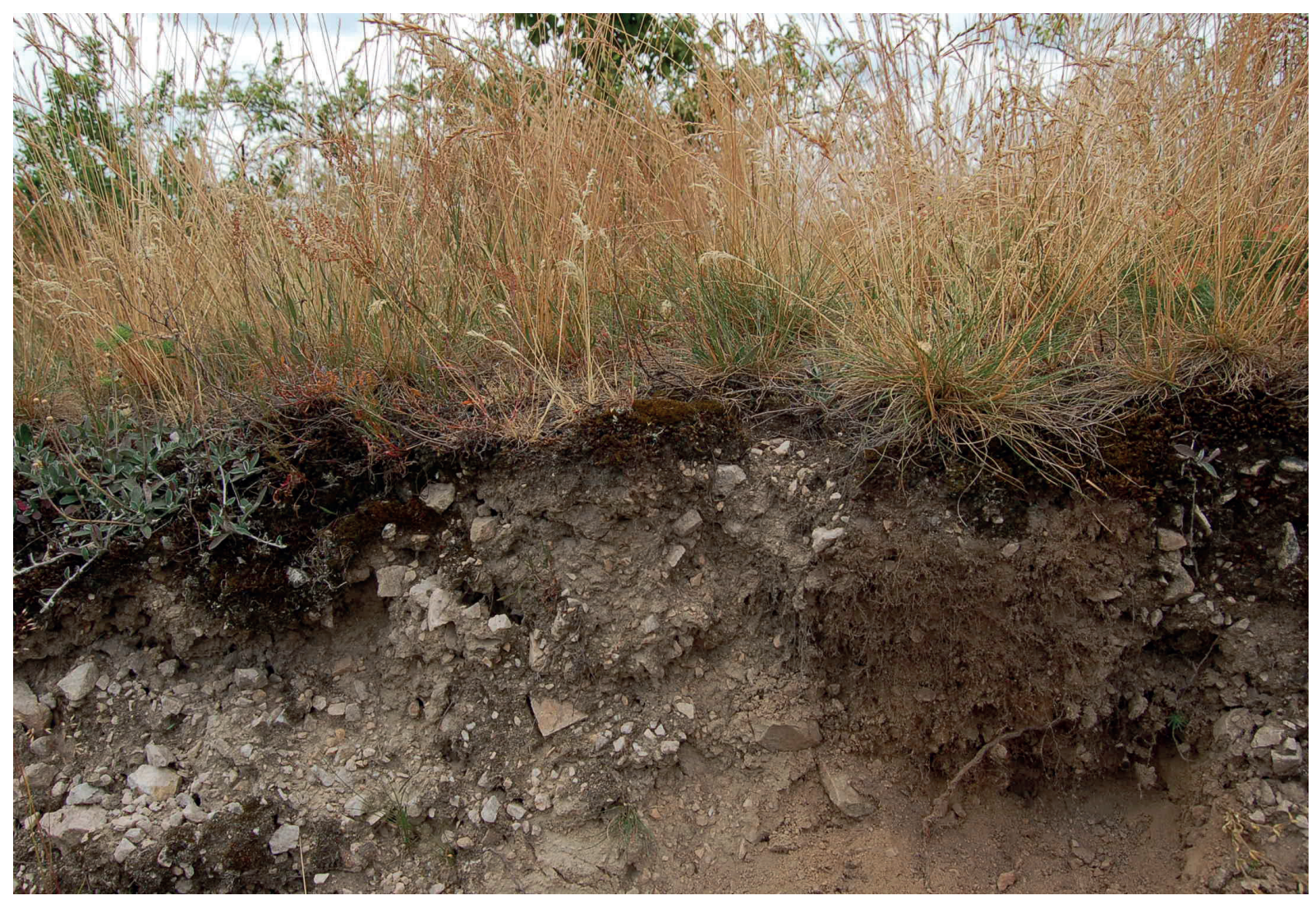

Figure 1: The soil of acidophilous dry grasslands is shallow with high amount of rocks (locality Starý vrch, Považský Inovec Mts). Photo: J. Koštál, June 2008.

Slika 1: Tla kisloljubnih suhih travišč so plitva in kamnita (Starý vrch, gorovje Považský Inovec). Foto: J. Koštál, junij 2008.

Upper Triassic origin. It is a part of the Mesozoic cliff zone called the klippen belt located between the Outer and the Central Western Carpathians (Biely 1996). In the quartzite areas, the dry grasslands developed locally at the sites with shallow rocky 'ranker' soil on south facing slopes with modest inclinations and at the hilltops (Figure 1). The soil $\mathrm{pH}(\mathrm{KCl})$ at the sites varies from 3.3 to 4.7 (Table 1 ).

\subsection{VEGETATION AND ENVIRONMENTAL DATA}

Based on the distribution of quartzite bedrock in Slovakia according to the geological maps (Geological map of the Slovak Republic, Biely 1975, Ivanička 1998, Ivanička 2007) and visual inspection of the satellite images of Slovakia in software Google Earth 6.0.2 we delimited localities of a potential occurrence of acidophilous grassland communities. We visited the selected localities in the field and in the case of acidophilous dry grassland presence we made phytosociological relevés following the standard principles of the Zürich-Montpellier school (Braun-Blanquet 1964, Westhoff \& van der Maarel 1973, Dengler et al. 2008) with the nine-degree scale (Barkman et al. 1964). All relevés included data on species composition, abundance and dominance as well as the standard site characteristics (altitude, latitude, longitude, slope, aspect, cover of herb layer and layer of bryophytes and lichens, height of herb layer, etc.), (Table 1, Appendix 1). All relevés were made between 2003 and 2009. The size of relevé plots was $16-25 \mathrm{~m}^{2}$; in one relevé (Table 1 , rel. 4) the plot size was smaller and represented the total size of the stand covered by the study vegetation. At the relevé plots we measured the average soil depth by repeated pricking of a long needle ( $3 \mathrm{~mm}$ wide in diameter) into the soil. We also gathered soil samples mixing the soil collected in root depth from three different spots within a plot. The soil samples were analysed to 


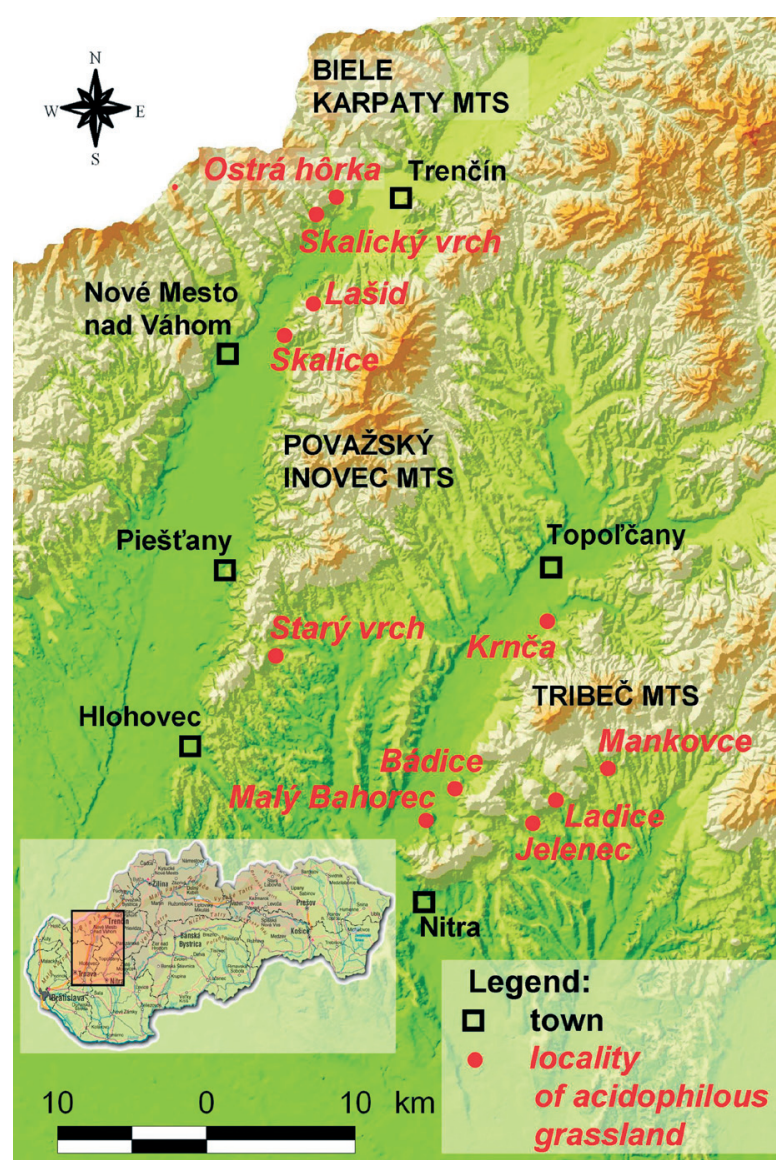

Figure 2: Map of study sites of the acidophilous dry grasslands located in western Slovakia (the Biele Karpaty Mts, Považský Inovec Mts and Tribeč Mts).

Slika 2: Zemljevid proučevanih rastišč acidofilnih suhih travišč zahodne Slovaške (gorovja Biele Karpaty, Považský Inovec in Tribeč).

determine the soil $\mathrm{pH}(\mathrm{KCl})$ in accordance with Fiala (1999).

The acidophilous dry grasslands on quartzite were confirmed and sampled in the following geomorphologic units of western and central Slovakia: Tribeč Mts, Považský Inovec Mts, Biele Karpaty Mts, Revúcka vrchovina Upland, Turčianska kotlina Basin and Lučenecká kotlina Basin. Seven relevés from Revúcka vrchovina Upland (localities Breznička, Selce, Uderiná), Turčianska kotlina Basin (Rudno) and Lučenecká kotlina Basin (Hrnčiarska Ves) in central Slovakia were rather heterogeneous and their species composition was shifted in succession towards the sub-xerophilous vegetation and mesic hay meadows. These relevés were selected as dissimilar to the rest of the data set in the outlier analysis performed by DCA (CANOCO 4.5 package; ter
Braak \& Šmilauer 2002). For this reason we decided to present only a relatively homogeneous data set including 21 relevés from 11 geographically contiguous localities in the Tribeč Mts, Považský Inovec Mts and Biele Karpaty Mts (western Slovakia) in the current paper (Figure 2). However, the omitted relevés are stored in the Slovak $\mathrm{Na}-$ tional Phytosociological Database (Hegedüšová 2007) and available for further studies.

\subsection{Classification anAlysis AND ASSIGN- MENT OF RELEVÉS TO ASSOCIATIONS}

Relevés were stored in a TURBOVEG database (Hennekens \& Schaminée 2001) and the data set edited using the JUICE 6.5 program (Tichý 2002). For numerical classification we used modified TWINSPAN algorithm (Roleček et al. 2009) with three pseudospecies cut levels $(0 \%, 5 \%, 25 \%)$ and total inertia as a measure of cluster heterogeneity. The constancy of differential species of the associations in Table 1 is over 50\%; in few individual cases (when the species was set as a diagnostic species of the association in a literature source and was absent from all relevés of the other association) we set as differential also species with constancy $\geq 30 \%$. The species constancies $\geq 50 \%$ are given in bold.

The two clusters created by the TWINSPAN analysis were assigned to the phytosociological associations by comparing the diagnostic species of both units to the published characteristics of the associations in Chytrý et al. (2007), Michálková (2007) and Dúbravková et al. (2010). Applying the Czech and Slovak expert systems for identification of syntaxa (Chytrý 2007, Janišová et al. 2007) and comparing of the relevés from Table 1 to clusters originated in the large-scale study Dúbravková et al. (2010) using the function 'match to clusters' with the frequency-positive fidelity index (FPFI) in the JUICE program (Tichý 2002) verified the assignment.

\subsection{Gradient analyses}

We defined the main environmental gradients responsible for variation in species composition on the basis of indirect ordination techniques, using the principal component analysis (PCA) based on square-root transformed data on species cover from the CANOCO 4.5 package (ter Braak 
\& Šmilauer 2002). For ecological interpretation of the ordination axes the average non-weighted indicator values of Borhidi (1993) for the relevés were plotted onto the PCA ordination diagram as supplementary environmental data.

The relationship between species composition and selected environmental factors was analysed by redundancy analysis (RDA) using the CANOCO 4.5 package. As the resulting gradient lengths in the DCA were short (1.98 for the first axis), the constrained linear ordination method of RDA was chosen for the evaluation of the independent (marginal), conditional, and pure effects of individual environmental variables. Species were not weighted by abundance, and no exclusion of rare species was applied. The following environmental variables were used in the RDA: average soil depth, soil $\mathrm{pH}(\mathrm{KCl})$, altitude, slope, latitude and longitude of the site. Forward selection was used for ranking environmental variables in order of importance (Palmer 1993). All studied environmental factors were tested by the Monte Carlo permutation test with unrestricted permutations (9999 permutations, $\mathrm{P}<0.05$ ). Finally, the pure effect (where the percentage variance is explained by the variable, while the remaining significant variables were used as co-variables) was calculated (ter Braak \& Prentice 1988). Pure variance is expressed as percentage of total inertia. To evaluate the independent (marginal) effects of individual variables, the variance explained by the variable when used as the only constraining variable was calculated. The conditional effect of a variable is given by the additional variance explained by the variable at the time it was included in the forward selection. Measured environmental variables that passed the forward selection in the RDA were correlated with ordination axes at $\mathrm{P}<0.001$ (Herben \& Münzbergová 2003).

\subsection{Nomenclature}

Nomenclature of taxa is in accordance with Marhold \& Hindák (1998). The syntaxa names and assignment of species to the diagnostic species of high-level syntaxa in Table 1 follow Janišová et al. (2007), Jarolímek \& Šibík (2008) and Dúbravková et al. (2010). The taxon Festuca valesiaca s.l. includes both a diploid species Festuca valesiaca and a tetraploid $F$. pseudodalmatica (Janišová et al. 2007, Šmarda 2008).

\section{RESULTS}

\subsection{Classification of Relevés}

Based on the precise selection of the suitable sites on quartzite bedrock in western Slovakia and using the modified TWINSPAN analysis we defined two associations of acidophilous dry grasslands.

Syntaxonomical scheme:

Festuco-Brometea Br.-Bl. et Tüxen ex Soó 1947

Festucetalia valesiacae Br.-Bl. et Tüxen ex Br.-Bl. 1949

Koelerio-Phleion phleoidis Korneck 1974

1. Avenulo pratensis-Festucetum valesiacae Vicherek et al. in Chytrý et al. 1997

2. Potentillo heptaphyllae-Festucetum rupicolae (Klika 1951) Toman 1970

\subsection{DesGription OF THE ASSOCIATIONS}

\subsubsection{Avenulo pratensis-Festucetum valesiacae Vicherek et al. in Chytrý et al. 1997}

Table 1, relevés 1-13

\section{Species composition and vegetation structure}

The association comprises semi-closed acidophilous dry grasslands dominated by Festuca valesiaca s.l. All specimens revised by the expert were determined as a tetraploid taxon Festuca pseudodalmatica. Plants of the two ploidy levels (Festuca pseudodalmatica and F. valesiaca) are very difficult to distinguish based on morphological characters in the field so they might have been confused by botanists in the past. Recent taxonomical study Šmarda (2008) showed that the two ploidity levels are not rigorously restricted to specific geological subsoils as well as that the ecological amplitude and extent of occurrence of Festuca pseudodalmatica is much wider then previously expected. The both species can even occur at the same sites. Regarding this knowledge, dominance of the tetraploid Festuca pseudodalmatica at the stands of Avenulo pratensis-Festucetum valesiacae is not surprising.

Besides the fescues, other grass species codominant in some stands are Anthoxanthum odoratum, Agrostis capillaris, and Arrhenatherum elatius. The generalist species of Central European 
dry grasslands with wide ecological amplitude (e.g. Acosta rhenana, Eryngium campestre, Galium verum agg., and Tithymalus cyparissias) that are diagnostic of the class Festuco-Brometea (Janišová et al. 2007) are abundantly present at the sites. The differential species distinguishing this vegetation unit from the other association are Aira caryophyllea, Bromus hordeaceus, Cerastium pumilum, Cruciata pedemontana, Festuca valesiaca s.l. (F. pseudodalmatica), Luzula campestris, Pilosella bauhini, Poa bulbosa, Scleranthus annuus agg., Vicia tetrasperma, and Viola kitaibeliana. An important component of the species composition are the acidophytes and species of soils poor in minerals (e.g. Acetosella vulgaris, Avenella flexuosa, Chondilla juncea, Hypochaeris radicata, Fasione montana, Pilosella officinarum, Potentilla argentea agg., Steris viscaria, and Trifolium arvense). Many of them are diagnostic species of the alliance Koelerio-Phleion phleoidis (Janišová et al. 2007, Dúbravková et al. 2010). Short annuals (e.g. Cerastium pumilum, Scleranthus annuus agg., Veronica verna, and Viola kitaibeliana) and bryophytes (e.g. Ceratodon purpureus, Hypnum cupressiforme, and Polytrichum juniperinum) are also abundant. Some species (e.g. Steris viscaria, Fasione montana, and Pilosella officinarum) bloom since the middle of May and create an attractive flower aspect (Figure 3). The relevés poor in species (e.g. rel. 2, 5) are typical of high abundance of bryophytes and their species composition resembles a pioneer community. The average cover of herbs is $78 \%$ and that of bryophytes and lichens $34 \%$. The height of plants at the stands is $27 \mathrm{~cm}$ on average.

\section{Synecology and distribution}

The current paper brings the very first data on distribution of the association in Slovakia. The stands of Avenulo pratensis-Festucetum valesiacae in western Slovakia occur exclusively at the NW and SE edges of the Tribeč Mts, in the areas of warm and dry climate at lower altitudes (200$310 \mathrm{~m}$ a.s.l.). The stands occur at the hilltops and ridges of small quartzite hills (localities Bádice, Jelenec, Krnča, Ladice, Mankovce, and Podhorany - Malý Bahorec) and sun-facing slopes of gentle inclinations $\left(1^{\circ}-10^{\circ}, \max .35^{\circ}\right)$. The secondary substitute stands can be found at the bottoms and edges of abandoned quartzite quarries (localities Bádice, Ladice, Jelenec, and Krnča). The sites are rare; they occur locally and in a small ex-

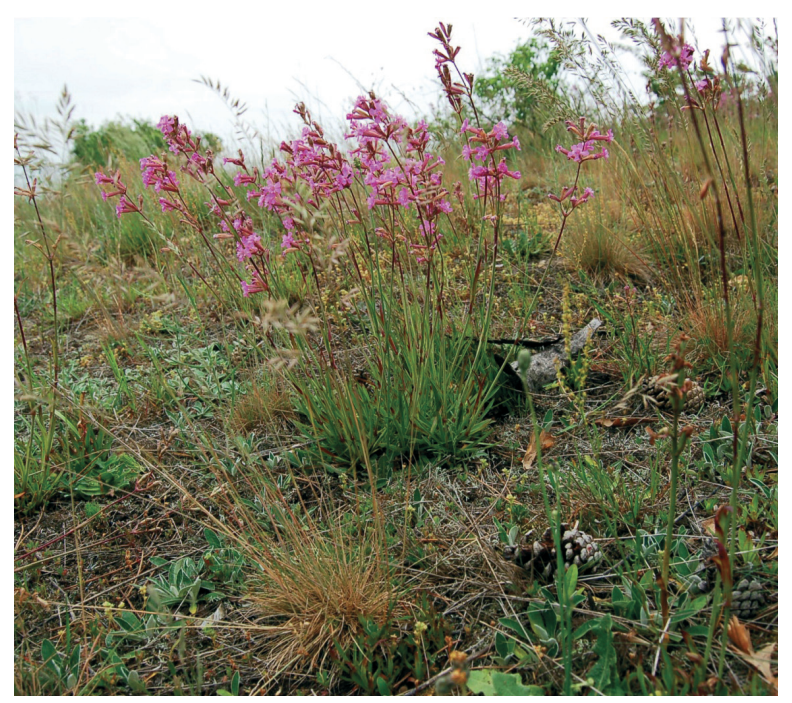

Figure 3: A stand of Avenulo pratensis-Festucetum valesiacae at locality Malý Bahorec, Tribeč Mts. Photo: J. Koštál, May 2008.

Slika 3: Sestoj asociacije Avenulo pratensis-Festucetum valesiacae na lokaciji Malý Bahorec, gorovje Tribeč. Foto: J. Koštál, maj 2008.

tent, mostly near the settlements where they were influenced by compressing of the soil as a result of grazing since they were used as pastureland in the past (Anonymus 1957).

The association represents a rare Central European type of dry grasslands. From other Central European countries, the association was recorded in the Czech Republic and Austria (SE edge of the Bohemian Massif, surroundings of the Neusiedler See); (Chytrý et al. 1997, Dúbravková et al. 2010). The average soil $\mathrm{pH}(\mathrm{KCl})$ at the sites in the Tribeč Mts is 4.0. Comparing to the typical soil $\mathrm{pH}$ of 5.3-6.7 at the sites of the association at the SE edge of the Bohemian Massif (Chytrý et al. 1997), the soil $\mathrm{pH}$ at the quartzite sites in western Slovakia is even more acidic.

\section{Variability}

On the basis of the modified TWINSPAN analysis we distinguished two variants of the association. The first variant (Table 1, rel. 1-8) represented stands rather resembling pioneer vegetation typical of occurrence of Fasione montana, Sedum sexangulare and Steris viscaria. Comparing to the second variant the herb layer $\left(\mathrm{E}_{1}\right)$ was more open (average cover 70\%) and cover of layer of bryophytes and lichens $\left(\mathrm{E}_{0}\right)$ was higher $(42 \%$ on 
average). The stands occurred at slopes of steeper inclinations $\left(5-35^{\circ}\right)$. The second variant (Table 1, rel. 9-13) represented closed stands on flat surfaces with inclination of $0-1^{\circ}$. Average cover of $\mathrm{E}_{1}$ was higher $(94 \%)$ and $\mathrm{E}_{0}$ lower (14\%). Since the two variants did not show any remarkable floristical differentiation and were not supported by PCA ordination analysis (Figure 6) as well as due to the relatively small number of relevés analysed we considered these variants as adaptation of vegetation to the local environmental conditions and stage of succession.

\section{Syndynamics and conservation status}

Avenulo pratensis-Festucetum valesiacae represents a substitute vegetation type on previously clearcut stands of acidophilous oak forests of the alliances Genisto germanicae-Quercion Neuhäusl et Neuhäuslová-Novotná 1967 and Quercion petraeae Zólyomi et Jakucs ex Jakucs 1960, which are considered to be the edaphic climax vegetation on shallow soils over quartzite in warm areas (Husová 1967). There occur grasslands dominated by Avenella flexuosa, heathlands of the alliance Genistion pilosae Duvigneaud 1942 and hay meadows of Arrhenatherion elatioris Koch 1926 in the surroundings of the study stands.

The association is a very rare vegetation type of Slovakia that occurs locally at small sized stands. Due to the island occurrence within other types of vegetation and actual abandonment of the sites, the vegetation is evidently threatened by successional changes. The rare and threatened plant species occur infrequently at the sites (e.g. the EN - endangered species Aira caryophyllea and Ventenata dubia, VU - vulnerable species $O r$ chis morio and LRnt - species of lower risk fasione montana; Feráková et al. 2001).

\subsubsection{Potentillo heptaphyllae-Festucetum rupicolae (Klika 1951) Toman 1970}

Table 1, relevés $14-21$

\section{Species composition and vegetation structure}

The association includes closed acidophilous dry grasslands dominated by Festuca rupicola. Other grass species (e.g. Agrostis capillaris, Anthoxanthum odoratum, and Arrhenatherum elatius) accompany the dominant. The species composition, similarly to the previous association, comprises the generalists of Central European dry grasslands (e.g. Acosta rhenana, Eryngium campestre, Galium verum agg., and Tithymalus cyparissias). The differential species of the association are Bromus erectus, Dianthus carthusianorum, Festuca rupicola, Fragaria viridis, Poa pratensis agg., Potentilla heptaphylla, Prunus spinosa, and Teucrium chamaedrys. Higher constancies also show Crataegus monogyna and Rosa canina agg. These are mostly sub-xerophilous species, herbs of hay meadows and successionally important shrubs that indicate a less xero- and thermophilous character of the vegetation comparing to the association Avenulo pratensis-Festucetum valesiacae and abandonment of the sites. Occurrence of the acidophytes and species of soils poor in minerals representing mostly the diagnostic species of the alliance Koelerio-Phleion phleioidis is similar to the previous association. The bryophytes and short herbs and annuals (e.g. Cerastium brachypetalum and Veronica verna) are also present. A colourful aspect in the middle of May bring flowers of Steris viscaria and Pilosella officinarum. The average cover of herbs is $85 \%$ and that of bryophytes and lichens $32.5 \%$. The height of plants at the stands is $28 \mathrm{~cm}$ on average.

\section{Synecology and distribution}

The localities of Potentillo heptaphyllae-Festucetum rupicolae occur in the Považský Inovec Mts (lokalities Starý vrch, Skalice and Lašid) and in the Biele Karpaty Mts (localities Skalický vrch and Ostrá hôrka). These sites are situated at the hills near the settlements and used for grazing in the past (Figure 4). The dry grasslands developed locally on flat surfaces or modest slopes of mostly sun facing expositions. The sites are situated at the altitudes of about $300-400 \mathrm{~m}$ a.s.l. that are roughly about 50-100 m higher comparing to the stands of Avenulo pratensis-Festucetum valesiacae. The stands of the association are rare, small in size and of local distribution.

In other parts of Slovakia, this vegetation occurs at the SE slopes of the Malé Karpaty Mts and in the Borská nížina Lowland (Chytrý et al. 1997, Zlinská 2000; Michálková 2007). Some stands with vegetation resembling the Potentillo heptaphyllae-Festucetum rupicolae were also documented from the quartzite areas of Slovakia located further to the east (Revúcka vrchovina 


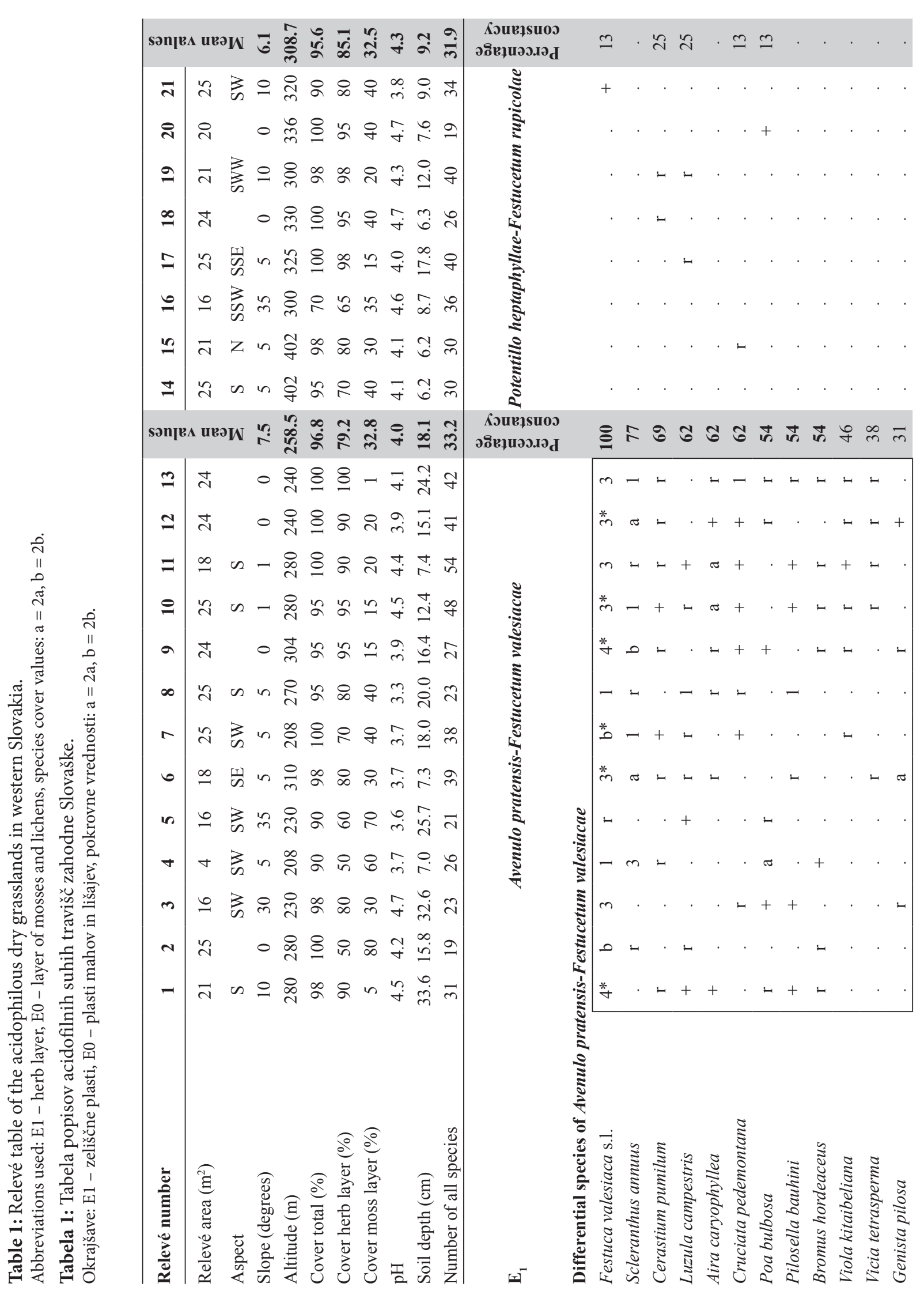




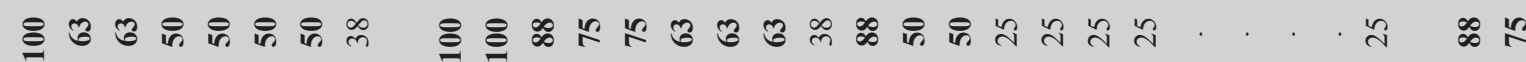

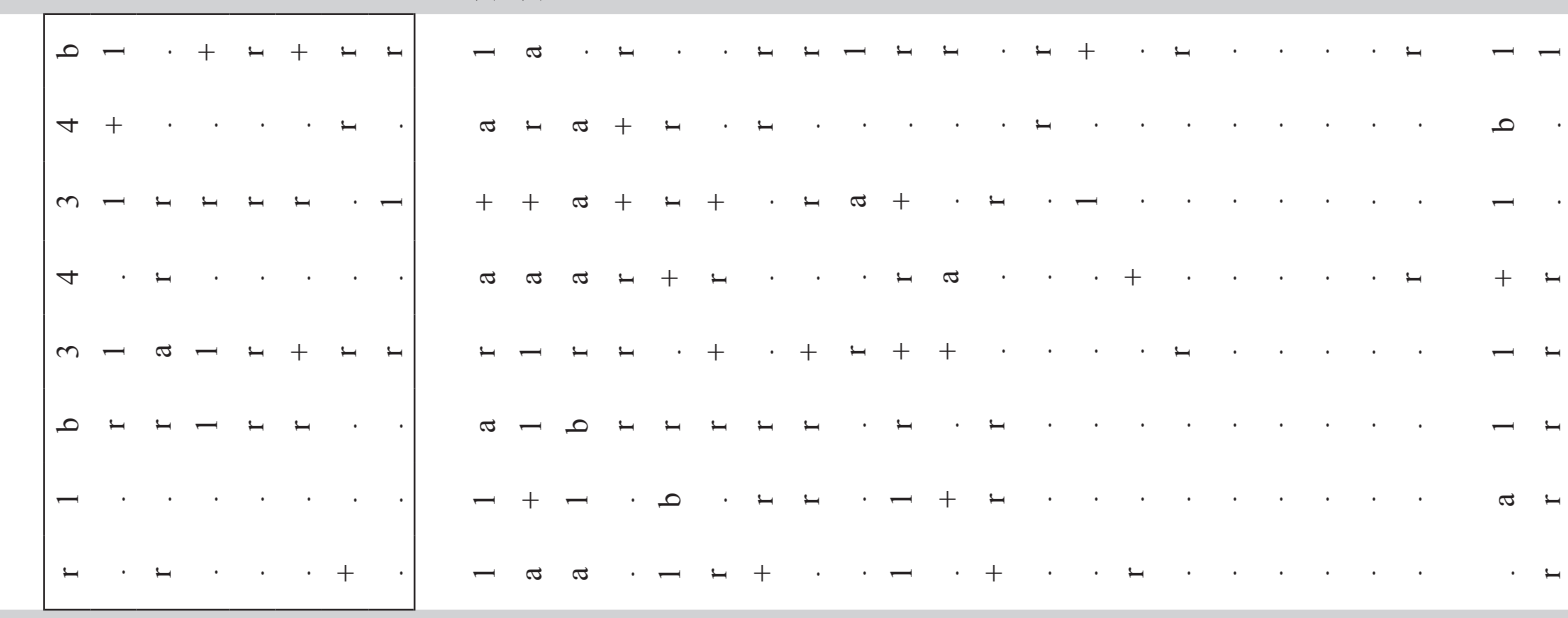

$\stackrel{n}{2} \cong$

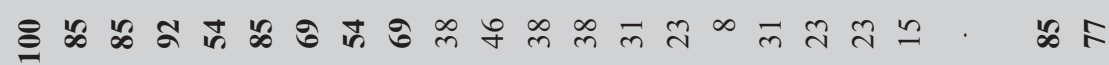

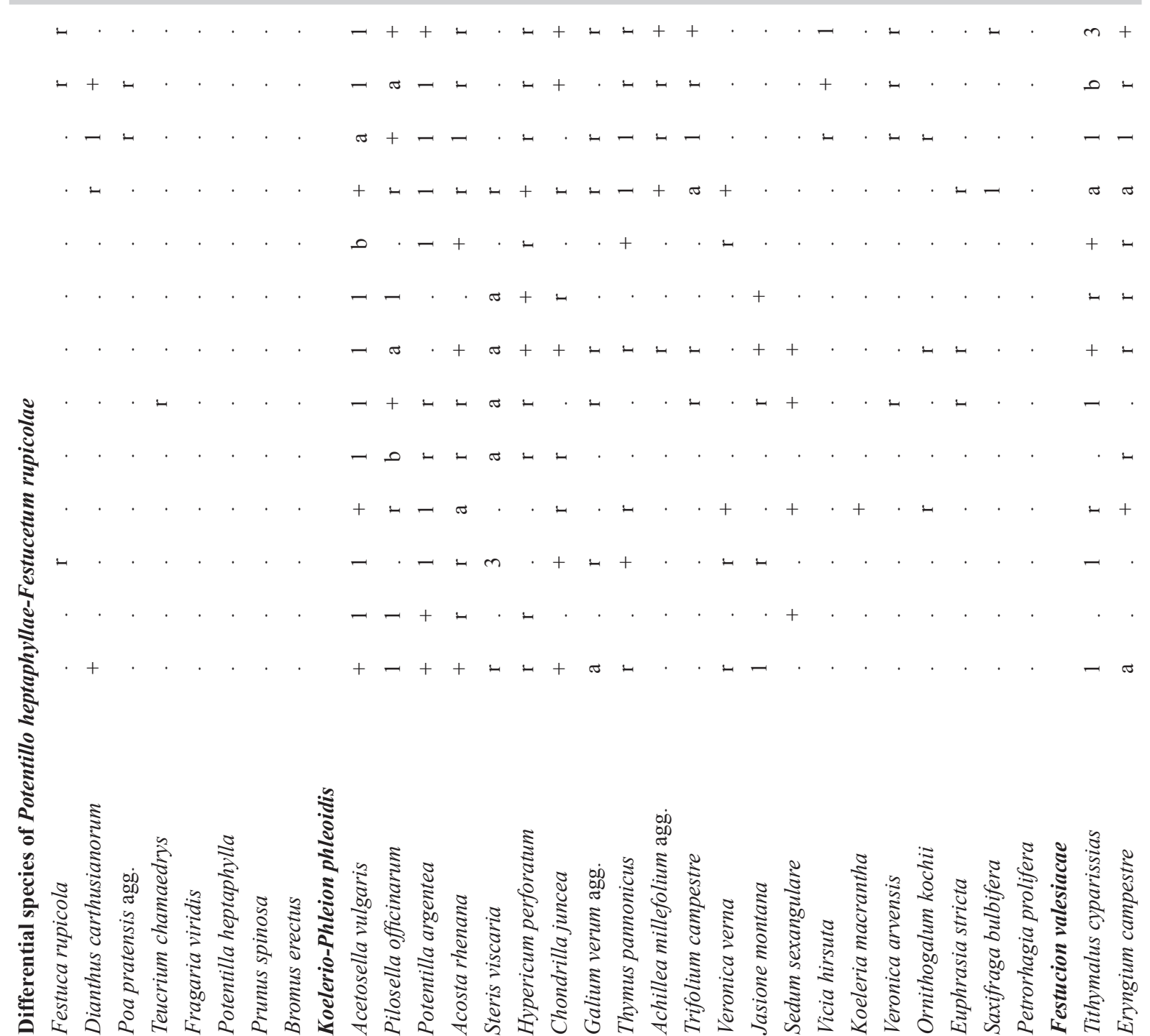




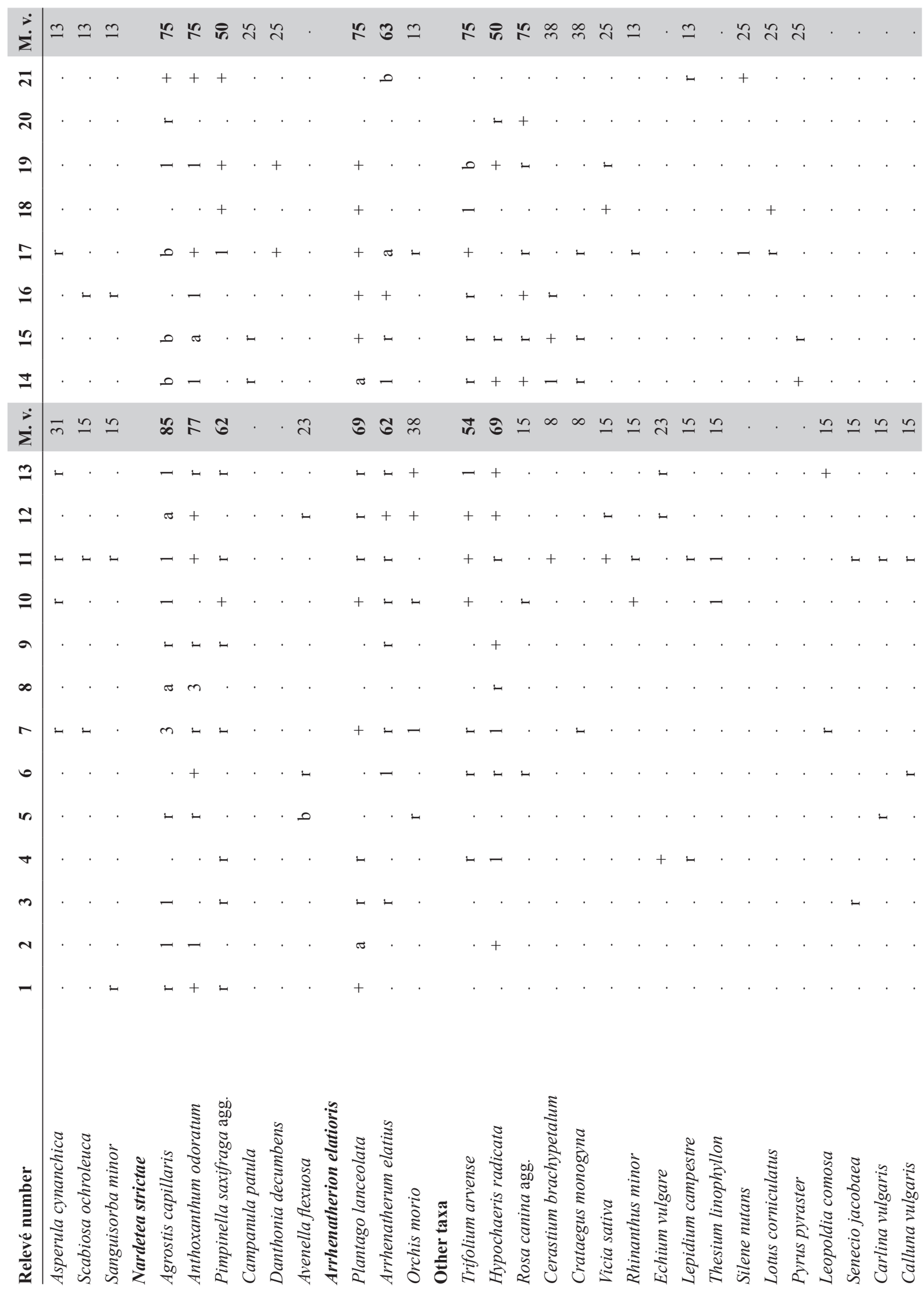



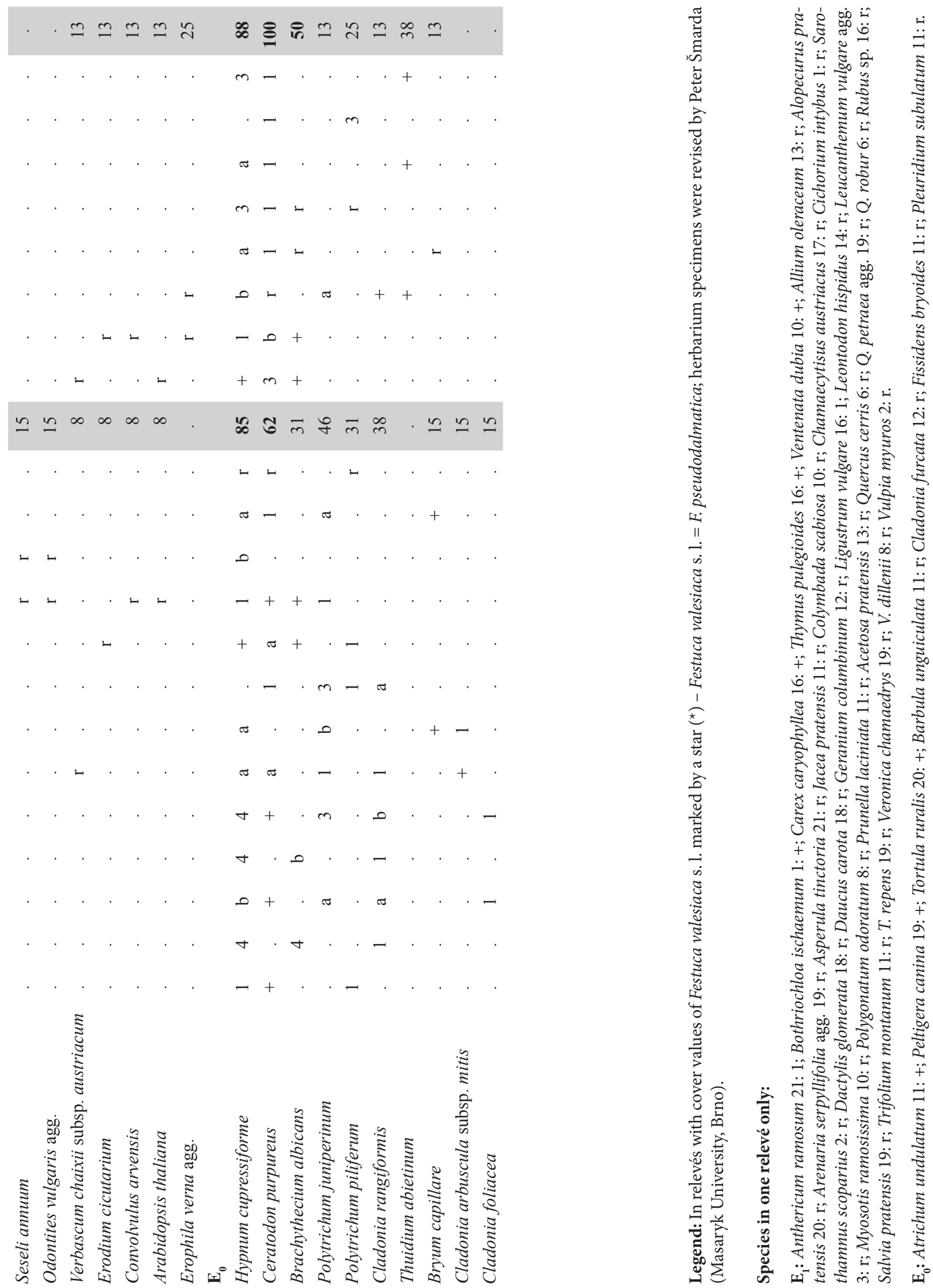


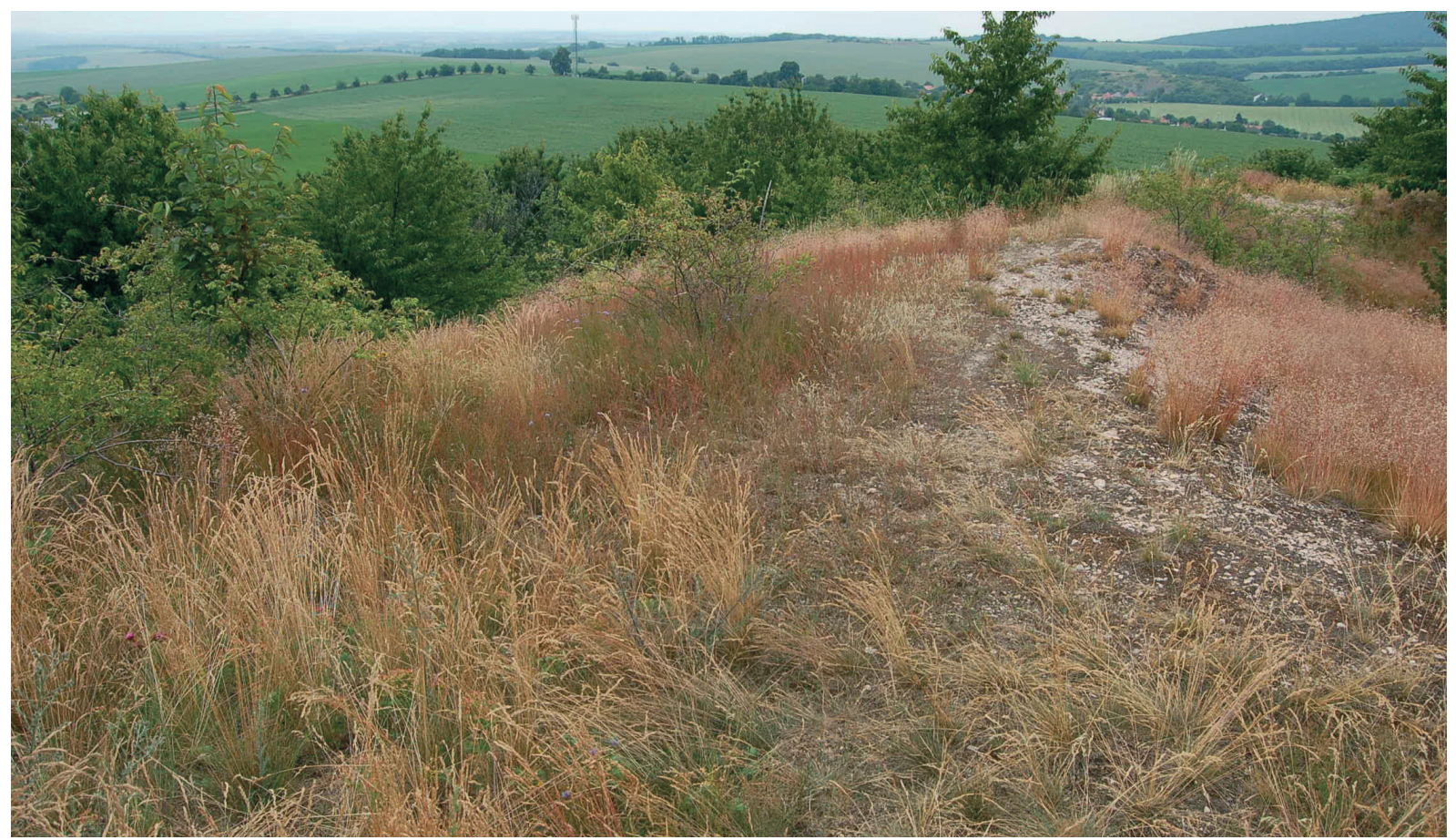

Figure 4: The stands of Potentillo heptaphyllae-Festucetum rupicolae occur frequently at the hilltops of small quartzite hills in a mosaik with stands of Avenela flexuosa (locality Starý vrch, Považský Inovec Mts). Photo: J. Koštál, June 2008.

Slika 4: Sestoji asociacije Potentillo heptaphyllae-Festucetum rupicolae se pogosto pojavljajo na vrhovih manjših kvarcitnih v mozaiku s sestoji vrste Avenela flexuosa (Starý vrch, gorovje Považský Inovec). Foto: J. Koštál, junij 2008.

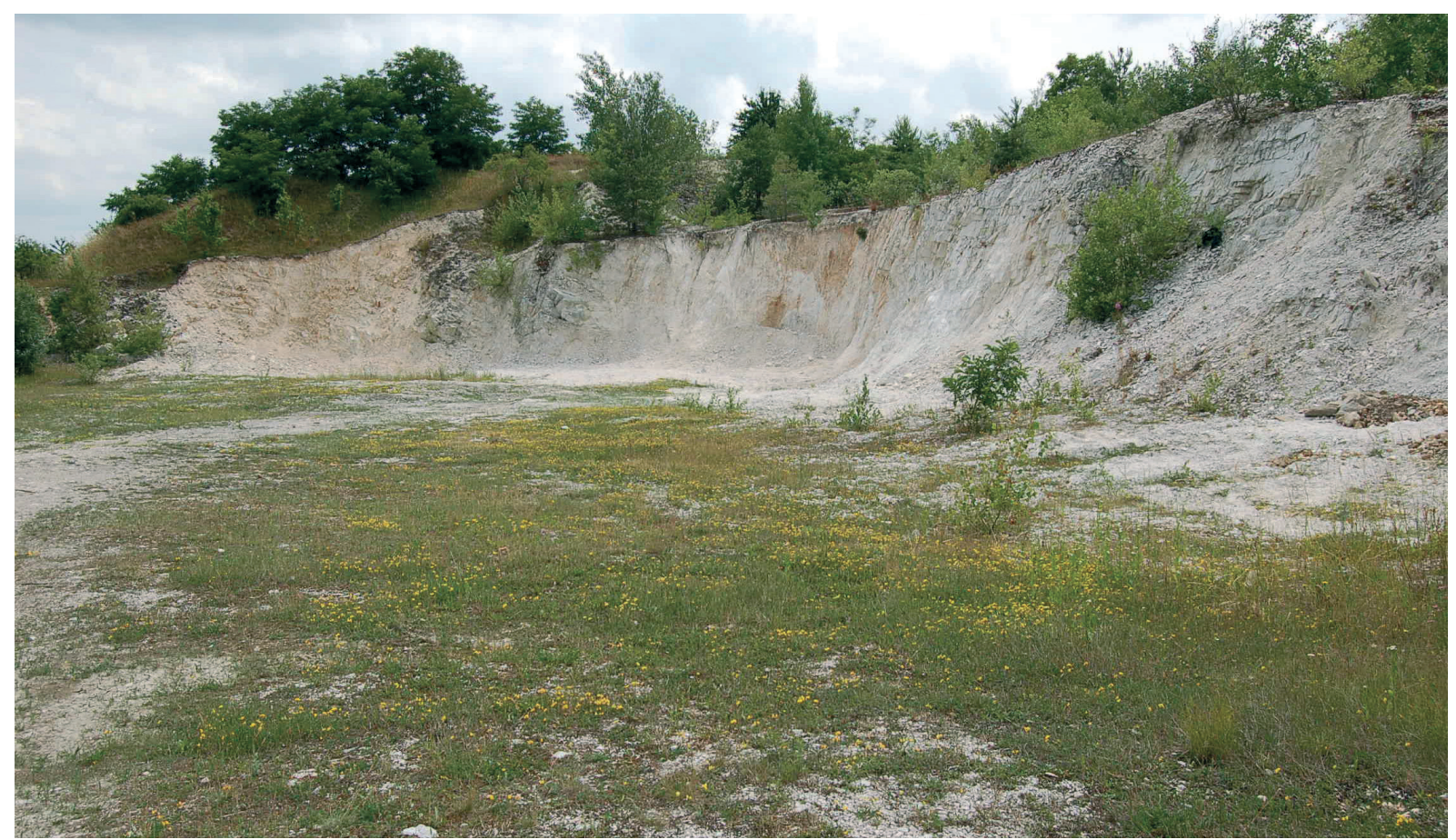

Figure 5: The acidophilous dry grassland often colonise substitute stands at abandoned quartzite quarries (a quarry at Starý vrch, Považský Inovec Mts). Photo: J. Koštál, June 2008.

Slika 5: Acidofilna suha travišča pogosto naseljujejo nadomestna rastišča v kamnolomih kvarcita (kamnolom pri lokaciji Starý vrch, gorovje Považský Inovec). Foto: J. Koštál, junij 2008. 
Upland, Turčianska kotlina Basin, Lučenecká kotlina Basin; Dúbravková ined., Koštál ined.). These stands, however, were rather heterogeneous and more mesic. Besides Slovakia, the association is distributed in the Czech Republic and in NE Austria (Chytrý et al. 1997; Chytrý et al. 2007; Dúbravková et al. 2010).

\section{Syndynamics and conservation status}

Potentillo heptaphyllae-Festucetum rupicolae represents a substitute vegetation type on previously clear-cut stands of acidophilous oak forests of the alliances Genisto germanicae-Quercion and Quercion petraeae. Vegetation types neighbouring to the stands of the association are mostly hay meadows (Arrhenatherion elatioris), sub-xerophilous grasslands (Bromion erecti Koch 1926) and grasslands dominated by Avenella flexuosa.

The association is one of the rare vegetation types of Slovakia and it is threatened by successional changes caused by cessation of traditional management. Secondary substitute sites of the association can be recently found in the abandoned quartzite quarries (Figure 5). The rare and threatened plant species occur infrequently at some sites (e.g. VU - vulnerable species Orchis morio and LRnt - species of lower risk fasione montana; Feráková et al. 2001).

\subsection{The GRADIENT ANALYSES}

\subsubsection{Indirect gradient analysis (PCA)}

Results of the principal component analysis (eigenvalues: $1^{\text {st }}$ axis $0.244,2^{\text {nd }}$ axis 0.158 , sum of all canonical eigenvalues 0.749 ; Table 2) support division of the data into two groups which represent the associations Avenulo pratensis-Festucetum valesiacae and Potentillo heptaphyllae-Festucetum rupicolae. The first and second axes explained $40.2 \%$ of the variance of species data and $47.8 \%$ of variance of species-environment relation. The first axis was positively correlated with altitude (correlation coefficient 0.5289) and negatively correlated with temperature indicator values $(-0.5200)$ and soil depth (-0.4455). Separation of the relevés to the two main groups located in the right and left parts of the ordination chart is mainly based on the gradient of temperature and altitude of the sites (Figure 6). The environmen- tal variables with the highest correlation coeficients to the second ordination axis are soil $\mathrm{pH}$ $(-0.3195)$ and altitude of the sites $(-0.302)$.

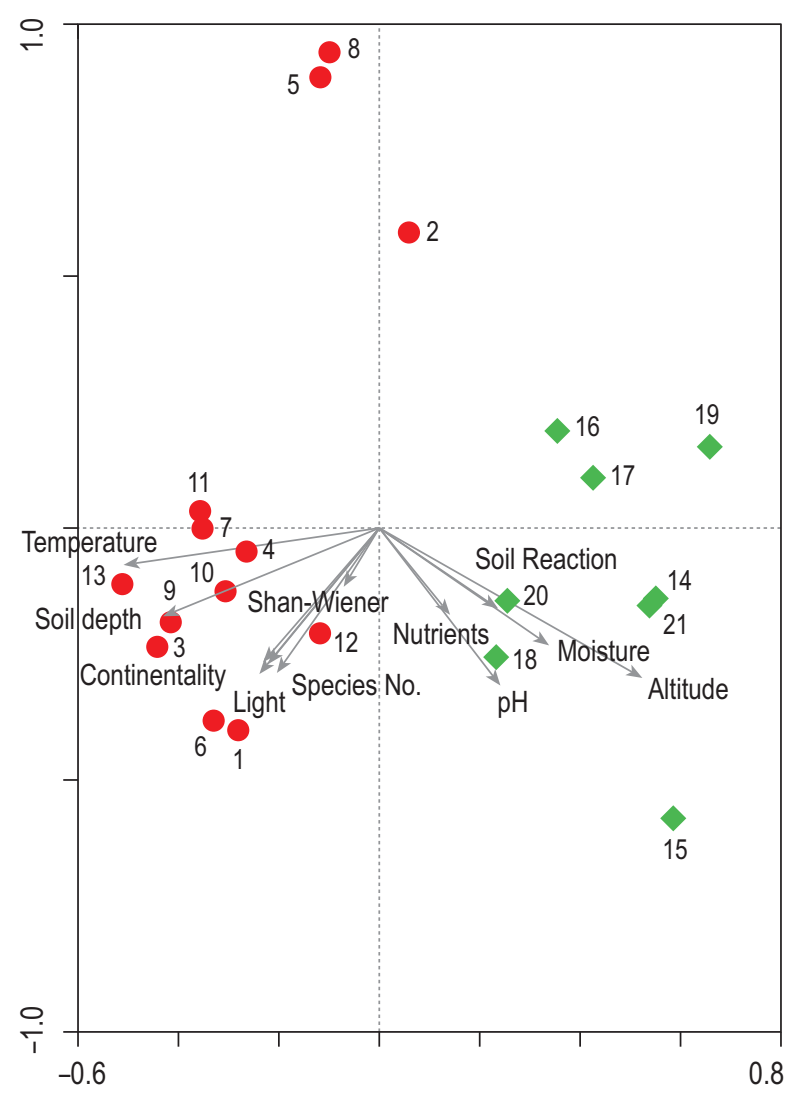

SAMPLES

Avenulo pratensis-Festucetum valesiacae

Potentillo heptaphyllae-Festucetum rupicolae

SUPPL. VARIABLES

Figure 6: Diagram of the principal component analysis (PCA) of the two acidophilous dry grassland associations based on square-root transformed data of species cover (first and second axes). Supplementary environmental variables represent unweighted indicator values of temperature, light, continentality, nutrients, soil reaction and moisture according to Borhidi (1993), Shannon-Wiener index, number of species, measured average value of soil depth and soil $\mathrm{pH}(\mathrm{KCl})$, and altitude of the plot.

Slika 6: Diagram analize glavnih component (PCA) dveh asociacij acidofilnih suhih travišč narejen s korenjenjem pokrovnih vrednosti (prva in druga os). Dodatne okoljske spremeljivke predstavljajo netehtane indikatorske vrednosti za temperaturo, svetlobo, kontinentalnost, hranila, reakcijo tal, in vlažnost po Borhidiju (1993), Shannon-Wienerjev indeks, število vrst, izmerjeno povprečno globino tal in $\mathrm{pH}(\mathrm{KCl})$, ter nadmorsko višino popisne ploskve. 
Relevés of the Avenulo pratensis-Festucetum valesiacae are located in the left and upper parts of the diagrams (Figures 6,7). It is a warmthdemanding association occuring at the sites at lower altitudes (the average altitude is $50 \mathrm{~m}$ smaller than at sites of the other community; Table 1). Generally, the soils are deeper and sites are dryer. The higher covers of weighty species displayed in Figure 7 reached mostly therrophytes with early spring phenophase (e.g. Aira caryophyllea, Cruciata pedemontana, Vicia tetrasperma, Viola kitaibeliana). Comparing to the Potentillo heptaphyllae-Festucetum rupicolae, the association is more open with lower average cover of herb layer. The relevés 2, 5, and 8 were separated off the diagram centre which was caused by higher covers of mosses, mostly Brachythecium albicans and Hypnum cupressiforme.

Group of relevés separated in the right part of the PCA diagrams (Figures 6,7) represent the association Potentillo heptaphyllae-Festucetum rupicolae. According to the results of PCA analysis, less thermophitic species occur in these grasslands and they are distributed at more humid sites with soil of somewhat less acidic $\mathrm{pH}$ (average $\mathrm{pH} 4.3$; Table 1) located at higher altitudes (Figure 6). Some sub-xerophilous species (e.g. Bromus erectus, Fragaria viridis, Lotus corniculatus, Potentilla heptaphylla) and succesionally important shrubs (Rosa canina) reach higher covers which indicates that the association is less thermo- and xerophilous, and relevés are influenced by successional shifts.

Table 2: The outputs of the PCA analysis of the phytocoenological relevés from Table 1.

Tabela 2: Rezultati PCA analize fitocenoloških popisov iz Tabele 1.

\begin{tabular}{lccccc}
\hline Axes & $\mathbf{1}$ & $\mathbf{2}$ & $\mathbf{3}$ & $\mathbf{4}$ & Total variance \\
\hline Eigenvalues & 0.244 & 0.158 & 0.123 & 0.074 & 1.000 \\
Cumulative percentage variance of species data & 24.4 & 40.2 & 52.5 & 59.9 & \\
Species-environment correlations & 0.948 & 0.937 & 0.912 & 0.964 & \\
Cumulative percentage variance of species-environment relation & 29.3 & 47.8 & 61.6 & 70.8 & \\
Sum of all eigenvalues & & & & & 1.000 \\
Sum of all canonical eigenvalues & & & & & 0.749 \\
\hline
\end{tabular}

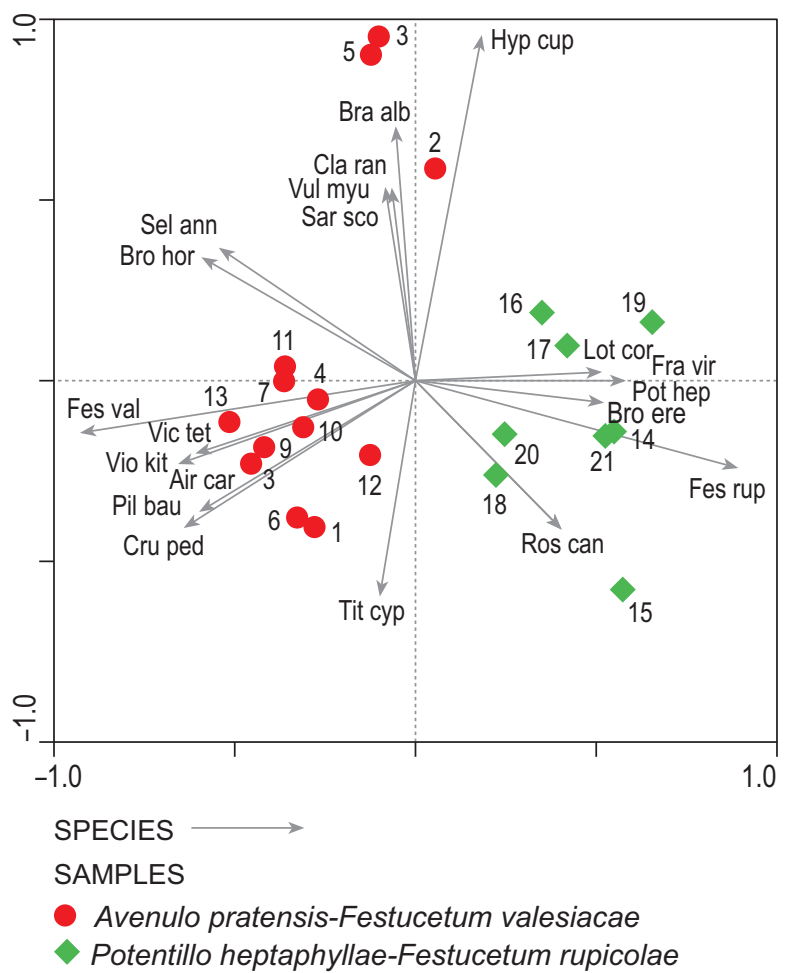

Figure 7: Diagram of the principal component analysis (PCA) of the acidophilous dry grasslands based on square-root transformed data of species cover (first and second axes). 20 species with weight over $25 \%$ are shown. The three-character abbreviations are as follows: Aira caryophyllea, Brachythecium albicans, Bromus erectus, B. hordeaceus, Cladonia rangiformis, Cruciata pedemontana, Festuca rupicola, F. valesiaca, Fragaria viridis, Hypnum cupressiforme, Lotus corniculatus, Pilosella bauhini, Potentilla heptaphylla, Rosa canina, Sarothamnus scoparius, Scleranthus annuus, Tithymalus cyparisias, Vicia tetrasperma, Viola kitaibeliana, Vulpia myuros. Explanations of symbols are in accordance with Figure 6.

Slika 7: Diagram analize glavnih component (PCA) acidofilnih suhih travišč narejen s korenjenjem pokrovnih vrednosti (prva in druga os). Prikazanih je 20 vrst s težo večjo kot $25 \%$. Okrajšava s tremi črkami predstavlja: Aira caryophyllea, Brachythecium albicans, Bromus erectus, B. hordeaceus, Cladonia rangiformis, Cruciata pedemontana, Festuca rupicola, F. valesiaca, Fragaria viridis, Hypnum cupressiforme, Lotus corniculatus, Pilosella bauhini, Potentilla heptaphylla, Rosa canina, Sarothamnus scoparius, Scleranthus annuus, Tithymalus cyparisias, Vicia tetrasperma, Viola kitaibeliana, Vulpia myuros. Razlaga simbolov je enaka kot pri Sliki 6. 


\subsubsection{Direct gradient analysis (RDA)}

The relationship between species composition and selected environmental factors was analysed using redundancy analysis (RDA). Sum of all canonical eigenvalues was 0.416 (eigenvalues: $1^{\text {st }}$ axis $0.219,2^{\text {nd }}$ axis 0.09 ; Table 3 ). The first RDA axis explained $21.9 \%$ of variance of the species data and $52.6 \%$ of the species-environment relationship, which means that $52.6 \%$ of the variability of our data set caused by the selected environmental factors was reflected by the first canonical axis. The 4 factors that were significant in the Monte Carlo permutation test (longitude, soil pH, slope and latitude) together explained $99.99 \%$ of compositional variance (Table 4). In the forward selection, longitude was included in the first step explaining $51.92 \%$ of data variation. Soil $\mathrm{pH}$ (KCl) was indicated as the second most important factor explaining $17.79 \%$ of data variation folloved by slope (15.14\%) and latitude (15.14\%). Of the significant environmental factors, longitude had the strongest pure effect on the variability of our data set (28.16\%). All variables passing the forward selection had a significant pure effect on variability of the data set. They explained
$78.64 \%$ of data variance when other significant variables were put into the RDA analysis as covariables.

Figure 8 shows positions of relevés of the two associations in relation to four environmental varibles passing the forward selection. The first ordination axis was positively correlated with longitude (correlation coefficient 0.9461) and negatively with latitude (-0.7511). Latitude also negatively correlates with the third axis (-0.5090). The environmental variable with the highest correlation to the second axis is soil pH $(-0.6824)$ and to the fourth axis is slope (0.7455). Relevés of the two studied associations were separated in the right and left parts of the ordination charts mainly based on longitude and latitude of the relevé plots (Figure 8). The geographical coordinates reflect the geographical position of relevés of the two studied associations which is strictly pronounced in our data set. All sites of Avenulo pratensis-Festucetum valesiacae without any exception were recorded in the Tribeč Mts that is located in the southeastern part of the study area (Figure 1). Potentillo heptaphyllae-Festucetum rupicolae exclusively occurs in the northwest in the Biele Karpaty Mts and Považský Inovec Mts.
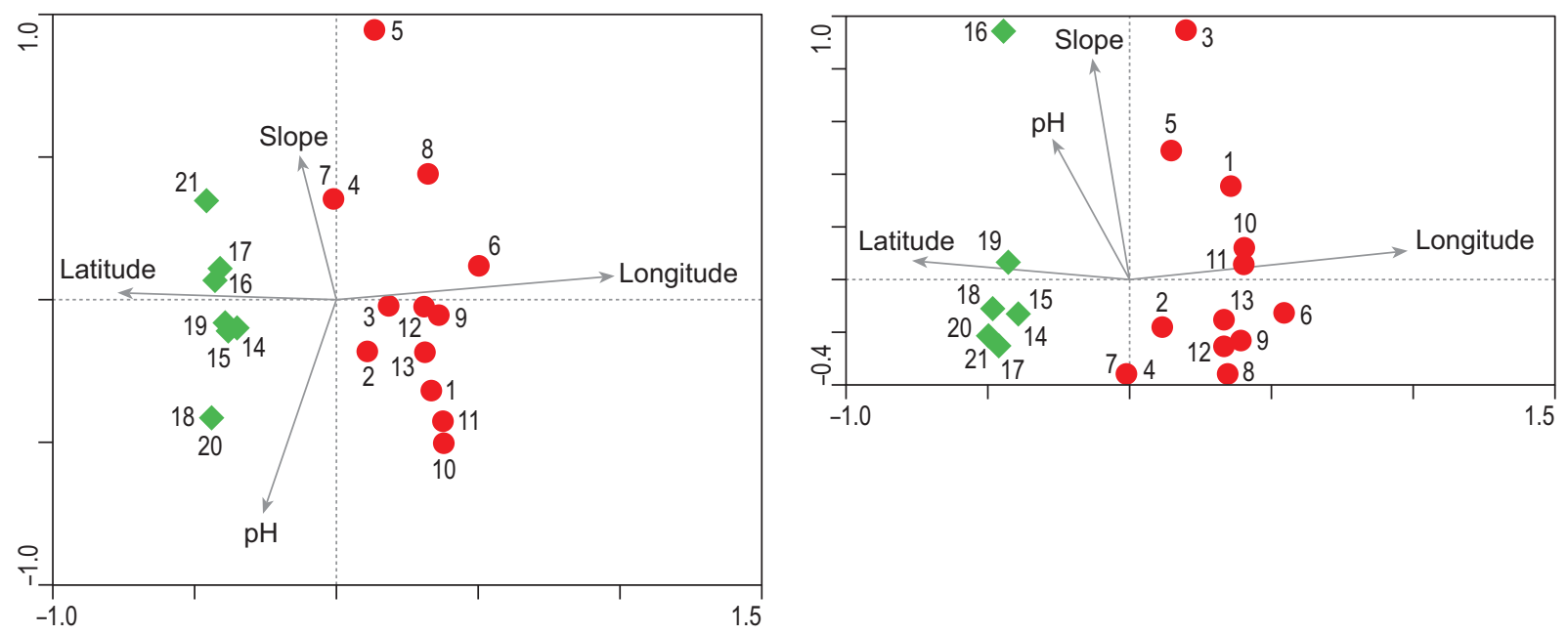

Figure 8: RDA diagrams of relevé positions of two acidophilous dry grassland associations (explanation of symbols are in accordance with Figure 6) in relation to four environmental factors passing the forward selection (9999 permutations, $\mathrm{P}<0.05$ ). RDA diagram of the $1^{\text {st }}$ and $2^{\text {nd }}$ axes (left) and $1^{\text {st }}$ and $4^{\text {th }}$ axes (right) are depicted. The two main axes display of variance of the species data and of the species-environment relationship. The significant environmental factors represent $99.99 \%$ of the data variation. Table 4 shows the order of inclusion of individual variables in forward selection.

Slika 8: Diagram analize RDA in položaj popisov dveh asociacij acidofilnih suhih travišč (razlaga simbolov je enaka kot pri Sliki 6) glede na štiri okoljske dejavnike v metodi izbiranja (9999 permutacij, $\mathrm{P}<0.05)$. Prikazana sta RDA diagrama prve in druge osi (levo) in prve in četrte osi (desno). Glavni osi prikazujeta $31.4 \%$ variabilnosti in $75.4 \%$ korelacije med vrstami in okoljem. Statistično značilni dejavniki predstavljajo 99.99\% variabilnosti podatkov. Tabela 4 predstavlja vrstni red vključevanja posameznih dejavnikov v metodi izbiranja. 
Table 3: The outputs of the RDA analysis of the phytocoenological relevés from Table 1.

Tabela 3: Rezultati analize RDA fitocenoloških popisov iz Tabele 1.

\begin{tabular}{lccccc}
\hline Axes & $\mathbf{1}$ & $\mathbf{2}$ & $\mathbf{3}$ & \multicolumn{4}{c}{ Total variance } \\
\hline Eigenvalues & 0.219 & 0.095 & 0.062 & 0.041 & 1.000 \\
Species-environment correlations & 0.955 & 0.887 & 0.83 & 0.883 & \\
Cumulative percentage variance of species data & 21.9 & 31.4 & 37.5 & 41.6 & 100.0 \\
Cumulative percentage variance of species-environment relation & 52.6 & 75.4 & 90.2 & & 1.000 \\
Sum of all eigenvalues & & & & & 0.416 \\
Sum of all canonical eigenvalues & & & &
\end{tabular}

Table 4: Redundancy analysis, results of forward selection. Marginal effect - percentage variance explained by individual variable while used as the only constraining variable. Conditional effect - additional variance explained by the variable at the time it was included in the stepwise selection. Pure effect - percentage variance explained by the variable after all variables significant when alone were used as co-variables (ter Braak \& Prentice 1988). Variance explained is shown as \% of total inertia. Legend: ns - not significant, ${ }^{*} \mathrm{P}<0.05,{ }^{*} \mathrm{P}<0.01,{ }^{* *} \mathrm{P}<0.001$.

Tabela 4: Analiza presežkov (RDA), rezultati vnaprejšnje izbire. Robni učinek - odstotek pojasnjene variance posamezne spremenljivke kot edine omejujoče spremenljivke. Pogojni učinek - dodatna pojasnjena variancaspremeljivke, ko je bila ta vključena v postopno izbiro. Čisti učinek - odstotek pojasnjene variance posamezne spremenljivke po tem, ko so vse ostale spremenljivke uporabljene kot ko-spremenljivke (ter Braak \& Prentice 1988). Pojasnjena variance je prikazana kot odstotek skupne variabilnosti. Legenda: ns - ni značilno, ${ }^{*} \mathrm{P}<0.05,{ }^{* *} \mathrm{P}<0.01,{ }^{* * *} \mathrm{P}<0.001$.

\begin{tabular}{|c|c|c|c|c|c|c|}
\hline Environmental variable & Marginal effect & $\%$ & $\begin{array}{l}\text { Conditional effect } \\
\text { (in selection order) }\end{array}$ & $\%$ & Pure effect & $\%$ \\
\hline Longitude & $0.216^{* * *}$ & 51.92 & $0.216^{* * * *}$ & 51.92 & $0.117^{\text {** }}$ & 28.16 \\
\hline Soil pH (KCl) & $0.087^{*}$ & 20.91 & $0.074^{*}$ & 17.79 & $0.080^{* *}$ & 19.23 \\
\hline Slope & $0.058^{\text {ns }}$ & 13.94 & $0.063^{*}$ & 15.14 & $0.067^{*}$ & 16.11 \\
\hline Latitude & $0.159^{* * *}$ & 38.22 & $0.063^{*}$ & 15.14 & $0.063^{*}$ & 15.14 \\
\hline Soil depth & $0.080^{\mathrm{ns}}$ & 19.23 & & & $0.060^{\mathrm{ns}}$ & 14.42 \\
\hline Altitude & $0.112^{* *}$ & 26.92 & & & $0.048^{\mathrm{ns}}$ & 11.54 \\
\hline Variance explained by significant variables & & & & 99.99 & & \\
\hline
\end{tabular}

\section{DISCUSSION AND CONCLUSIONS}

\subsection{SPECIES COMPOSITION}

The diagnostic species of Avenulo pratensis-Festucetum valesiacae published in relevant syntaxonomical papers (Chytrý et al. 2007, Dúbravková et al. 2010) and the differential species of the association assign in the current study (Table 1) differ partially. The species in common are the dominant grass Festuca valesiaca s.l. and also Genista pillosa and Poa bulbosa. Other species preferably occurring in Avenulo pratensis-Festucetum valesiacae that were assigned in the literature sources as diagnostic although they do not reach the threshold criteria set in this paper to be considered as differential are Asperula cynynchica, Avenella flexuosa, Calluna vulgaris, Cladonia foliacea, Euphrasia stricta, and Thymus pannonicus. Other diagnostic species of Avenulo pratensis-Festucetum valesiacae that equally occur in both associations in Table 1 are Acetosella vulgaris, Achillea millefolium agg., Acosta rhenana, Anthoxanthum odoratum, Eryngium campestre, Hypericum perforatum, Fasione montana, Koeleria macrantha, Sedum sexangulare, Trifolium arvense, Pilosella officinarum, Cladonia rangiformis, and Polytrichum piliferum. The data set from western Slovakia is totally lacking e.g. Agrostis vinealis, Armeria vulgaris, Gagea bohemica, Helichrysum arenarium, and Thymus praecox that are the diagnostic species of higher fidelities in the above-mentioned publications. On the other hand, Aira caryophyllea occurs with higher frequencies specifically in the relevés from the Tribeč Mts. This is a local peculiarity not typical for the sites of the association Avenulo pratensis-Festucetum valesiacae in other areas. 
Comparing the diagnostic species of Potentillo heptaphyllae-Festucetum rupicolae listed in Chytrý et al. (2007) and Michálková (2007) and the differential species from Table 1, we found 3 species in common (Festuca rupicola, Dianthus carthusianorum, and Teucrium chamaedrys). A species preferably occurring in this association that was assigned in the literature as diagnostic although in this paper it does not reach the threshold criteria for the differential species is Petrorhagia prolifera. Other diagnostic species of Potentillo heptaphyllae-Festucetum rupicolae that equally occur in both associations in this paper are Acetosella vulgaris, Koeleria macrantha, Trifolium arvense, T. campestre, Pilosella officinarum, Potentilla argentea, Sedum sexangulare, Steris viscaria, Tithymalus cyparisias, and Cladonia rangiformis.

In spite of the above-mentioned differences, the study sites show a close relation to the associations' descriptions in terms of species composition and the preferred environmental conditions. The reason why the data of acidophilous dry grasslands from quartzite of western Slovakia slightly differ from the published characteristics of the associations may be ascribed to the fact, that these data were not included in the datasets used for calculation of diagnostic species in Michálková (2007) and Dúbravková et al. (2010) with an exception of 2 reléves included in the second publication mentioned. What is more, there were not described any other acidophilous dry grassland associations dominated by Festuca valesiaca and $F$. rupicola in the territory of Central Europe. Therefore we considered these stands as data that shall enlarge not only the total distribution of these acidophilous dry grassland associations but also their internal variability. However, the differential species assigned in the current paper shall not to be used as diagnostic species of the two study associations because they are based on limited number of relevés originated from a geographically small area.

\subsection{ENVIRONMENTAL CONDITIONS AND ORDINATION ANALYSES}

According to Chytrý et al. (2007), the association Avenulo pratensis-Festucetum valesiacae occurs in dry regions with average yearly rainfall of $550 \mathrm{~mm}$ or lower. The more mesophilous association Potentillo heptaphyllae-Festucetum rupicolae occupies sites of similar soils but located in more humid regions. This moisture gradient is also valid to the sites of the associations in western Slovakia. In southern Moravia in the Czech Republic, however, both associations occur practically at nearby sites on southeastern foothills of the Bohemian Massif (Chytrý et al. 2007). In western Slovakia, the occurrence of the associations follows the humidity ranges more precisely and the occurrence of each association is limited in separate mountain areas. The sites of the studied associations do not occur close to each other but in climatically (considering the average yearly temperatures and rainfall) and topographically (altitude) pronounced areas. As an important factor representing the moisture gradient of the sites of the two associations is the precipitation range during the growing season and the average rainfall in July (in the Tribeč Mts - up to $60 \mathrm{~mm}$; Považský Inovec and Biele Karpaty Mts - up to 80 mm; Faško \& Štastný 2002b).

The strict spatial differentiation of sites of the two associations is most probably the reason of the great importance of longitude and latitude proved by the RDA analysis with forward selection. Longitude representing the west-east gradient also reflects partially the continental and oceanic influences expressed in the species composition of the acidophilous dry grasslands. However the portions of variance explained by significant variables passed forward selection remain surprisingly high. Out of the six studied environmental variables four passed the forward selection at $\mathrm{P}<0.05$. An interesting fact is however, that the altitude did not pass the forward selection although it was the factor with the highest correlation with the first PCA axis.

\subsection{The Koelerio-Phleion Phleoidis ALLIANCE}

We assigned the two associations of interest to the Koelerio-Phleion phleoidis alliance following the traditional classification of Central European acidophilous dry grasslands, although Dúbravková et al. (2010) showed a close relation of this vegetation to the alliance Festucion valesiacae Klika 1931. We acknowledge that classification of the acidophilous dry grasslands in the CarpathoPannonian region of the eastern Central Europe to higher syntaxa is rather tangled, however we did not aim to answer the question of the Koelerio-Phleion phleoidis delimitation in the current 
paper. To solve this problem efficiently, following questions need to be addressed in some subsequent supraregional studies: (1) is the alliance Koelerio-Phleion phleoidis supported at all, (2) do the acidophilous dry grassland associations in eastern Central Europe belong to the same alliance as those originally described by Korneck (1974) from western Gemany, and (3) what is the relation of Koelerio-Phleion phleoidis to other higher units that include acidophilous vegetation, e.g. Koelerio-Corynephoretea Klika in Klika et Novák 1941? Although this paper does not deal with the topics outlined, the new original data published here might be an important component necessary for the later studies.

\section{Acknowledgements}

We are grateful to Milan Chytrý for consulting the classification issues; Anna Kubinská and Anna Petrášová for determination of the bryophytes; Anna Lackovičová for identification of the lichens; Petr Šmarda for determination of specimens of the genus Festuca and Ján Jahna for consultation on the geology of the sites. D. D. was supported by the Science Grant Agency of the Ministry of Education of the Slovak Republic and Slovak Academy of Sciences (VEGA 2/0181/09) and a grant through the EEA Financial Mechanism and the Norwegian Financial Mechanism and the state budget of the Slovak Republic (SK0115).

\section{APPENDIX 1:}

Origin of the relevés in Table 1.

\section{PRILOGA 1:}

Lokacije popisov iz Tabele 1.

The entries are structured as follows: relevé number; description of the locality; longitude; latitude; geology; soil; height of the herb layer; date (year/month/day); field number; a remark. Author of all relevés is J. Koštál.

01. Tribeč Mts, Ladice, a quartzite quarry NW of the village, $1 \mathrm{~m}$ of the SE edge of the quarry; $18^{\circ} 15^{\prime} 06.72^{\prime \prime} \mathrm{E}$; $48^{\circ} 24^{\prime} 04.35^{\prime \prime} \mathrm{N}$; quartzite; shallow soil; 25 cm; 2003/05/25; 11/2003; Festuca valesiaca s.l. $=F$. pseudodalmatica .
02. Tribeč Mts, Bádice, a quartzite quarry located $500 \mathrm{~m}$ E of the village; $18^{\circ} 08^{\prime} 15.54^{\prime \prime} \mathrm{E}$; $48^{\circ} 23^{\prime} 50.99 " \mathrm{~N}$; quartzite; shallow rocky soil; $25 \mathrm{~cm} ; 2003 / 06 / 06 ; 15 / 2003$.

03. Tribeč Mts, Jelenec, an edge of a quarry located near the cemetery about $1.25 \mathrm{~km} \mathrm{SE}$ of the water reservoir Jelenec; $18^{\circ} 13^{\prime} 37.76^{\prime \prime} \mathrm{E}$; $48^{\circ} 23^{\prime} 12.82$ " N; quartzite; shallow soil; $30 \mathrm{~cm}$; 2003/05/17; 02/2003.

04. Tribeč Mts, Podhorany, Malý Bahorec Mt., 5 $\mathrm{m}$ to the SW of the hilltop; $18^{\circ} 06^{\prime} 05.58^{\prime \prime} \mathrm{E}$; $48^{\circ} 23^{\prime} 13.57$ " N; quartzite; shallow rocky soil; $15 \mathrm{~cm} ; 2008 / 05 / 20 ; 25 / 2008$.

05. Tribeč Mts, Jelenec, an edge of a quarry located near the cemetery about $1.25 \mathrm{~km} \mathrm{SE}$ of the water reservoir Jelenec; $18^{\circ} 13^{\prime} 38^{\prime \prime} \mathrm{E}$; $48^{\circ} 23^{\prime} 12.75^{\prime \prime} \mathrm{N}$; quartzite; shallow rocky soil; $15 \mathrm{~cm} ; 2003 / 05 / 17 ; 03 / 2003$.

06. Tribeč Mts, Mankovce, Hôrka Hill (310 m a.s.l.), $15 \mathrm{~m}$ to the SEE of the hilltop; $18^{\circ}$ 19' $19.67^{\prime \prime} \mathrm{E}$; $48^{\circ} 25^{\prime} 51.52^{\prime \prime} \mathrm{N}$; quartzite; shallow rocky soil; $50 \mathrm{~cm}$; 2008/06/03; 55/2008; Festuca valesiaca s.l. $=$ F. pseudodalmatica .

07. Tribeč Mts, Podhorany, Maly Bahorec Hill, $40 \mathrm{~m}$ to the SSW of the hilltop; $18^{\circ} 06^{\prime} 04.89^{\prime \prime} \mathrm{E}$; $48^{\circ} 23^{\prime} 13.05^{\prime \prime} \mathrm{N}$; quartzite; shallow rocky soil; 30 cm; 2008/05/20; 24/2008; Festuca valesiaca s.l. $=$ F. pseudodalmatica .

08. Tribeč Mts, Krnča, a quartzite quarry at the W edge of the village; $18^{\circ} 14^{\prime} 36.03^{\prime \prime} \mathrm{E}$; $48^{\circ} 32^{\prime} 36.29^{\prime \prime} \mathrm{N}$; quartzite; shallow soil; $30 \mathrm{~cm} ; 2003 / 05 / 23 ; 07 / 2003$.

09. Tribeč Mts, Ladice, a quarry located $20 \mathrm{~m}$ to the $\mathrm{W}$ of the elevation point $304 \mathrm{~m}$ a.s.l.; $18^{\circ} 14^{\prime} 58.29^{\prime \prime} \mathrm{E}$; $48^{\circ} 24^{\prime} 02.56^{\prime \prime} \mathrm{N}$; quartzite; shallow rocky soil; $20 \mathrm{~cm} ; 2008 / 05 / 23 ; 40 / 2008$; Festuca valesiaca s.l. $=$ F. pseudodalmatica .

10. Tribeč Mts, Ladice, a small quarry near a cherry orchard; $18^{\circ} 15^{\prime} 08.98^{\prime \prime} \mathrm{E}$; $48^{\circ} 23^{\prime} 58.07^{\prime \prime} \mathrm{N}$; quartzite; shallow rocky soil; $10-40 \mathrm{~cm}$; 2008/06/03; 54/2008; Festuca valesiaca s.l. = F. pseudodalmatica.

11. Tribeč Mts, Ladice, a small quarry near the vineyards; $18^{\circ} 15^{\prime} 09.05^{\prime \prime} \mathrm{E}$; $48^{\circ} 23^{\prime} 58.27^{\prime \prime} \mathrm{N}$; quartzite; shallow rocky soil; $35 \mathrm{~cm} ; 2008$ / 06/03; 53/2008.

12. Tribeč Mts, Jelenec, an edge of a quarry located near the cemetery; $18^{\circ} 13^{\prime} 38.55^{\prime \prime} \mathrm{E}$; $48^{\circ} 23^{\prime} 15.84 " \mathrm{~N}$; quartzite; shallow rocky soil; 30-100 cm; 2008/05/23; 36/2008; Festuca valesiaca s.l. $=F$. pseudodalmatica .

13. Tribeč Mts, Jelenec, an edge of a quarry located near the cemetery; $18^{\circ} 13^{\prime} 38.08^{\prime \prime} \mathrm{E}$; 
$48^{\circ} 23^{\prime} 14.88 " \mathrm{~N}$; quartzite; shallow rocky soil; $35 \mathrm{~cm}$; 2008/05/23; 37/2008.

14. Biele Karpaty Mts, Chocholná-Velčice, Skalický vrch Mt., an elevation point Pod hájom (402 m a.s.1.); $17^{\circ} 55^{\prime} 26.82^{\prime \prime} \mathrm{E} ; 48^{\circ} 53^{\prime} 06.08^{\prime \prime} \mathrm{N}$; quartzite; shallow rocky soil; $15-35 \mathrm{~cm}$; 2009/ 05/13; 01/2009.

15. Biele Karpaty Mts, Chocholná-Velčice, Skalický vrch Mt., an elevation point Pod hájom (402 m a.s.1.); $17^{\circ} 55^{\prime} 27.01^{\prime \prime} \mathrm{E}$; $48^{\circ} 53^{\prime} 07.43^{\prime \prime} \mathrm{N}$; quartzite; shallow rocky soil; $10-35 \mathrm{~cm} ; 2009 /$ 05/13; 02/2009.

16. Biele Karpaty Mts, Drietoma, Ostrá hôrka Mt., SW slope; $17^{\circ} 57^{\prime} 20.64^{\prime \prime} \mathrm{E}$; $48^{\circ} 54^{\prime}$ $03.55 " \mathrm{~N}$; quartzite; shallow rocky soil; $15 \mathrm{~cm}$; 2009/05/13; 03/2009.

17. Považský Inovec Mts, Beckov, Skalice Mt.; $17^{\circ} 54^{\prime} 03.47^{\prime \prime} \mathrm{E} ; \quad 48^{\circ} 46^{\prime} 38.08^{\prime \prime} \mathrm{N} ; \quad$ quartzite; shallow rocky soil; $35 \mathrm{~cm} ; 2008 / 06 / 20 ; 58 / 2008$.

18. Považský Inovec Mts, Šalgovce, Starý vrch Mt., a NW edge of a quarry; $17^{\circ} 53^{\prime} 14.87^{\prime \prime} \mathrm{E}$; $48^{\circ} 31^{\prime} 51.52^{\prime \prime} \mathrm{N}$; quartzite; shallow rocky soil; $35 \mathrm{~cm} ; 2008 / 06 / 17 ;$ 57/2008.

19. Považský Inovec Mts, Beckov, Lašid Mt., SW slope, at the forest edge; $17^{\circ} 55^{\prime} 19.91^{\prime \prime} \mathrm{E}$; $48^{\circ} 47^{\prime} 08.58 " \mathrm{~N}$; quartzite; shallow rocky soil; $40 \mathrm{~cm} ; 2008 / 06 / 20 ; 60 / 2008$.

20. Považský Inovec Mts, Šalgovce, Starývrch Mt., above an abandoned quarry; $17^{\circ} 53^{\prime} 19.47^{\prime \prime} \mathrm{E}$; $48^{\circ} 31^{\prime} 49.65 " \mathrm{~N}$; quartzite; shallow rocky soil; $50 \mathrm{~cm} ; 2008 / 06 / 17 ; 56 / 2008$.

21. Považský Inovec Mts, Beckov, Skalice Mt., $50 \mathrm{~m} \mathrm{SW}$ of the hilltop; $17^{\circ} 54^{\prime} 01.12^{\prime \prime} \mathrm{E}$; $48^{\circ} 46^{\prime} 36.88^{\prime \prime} \mathrm{N}$; quartzite; shallow rocky soil; 25-80 cm; 2008/06/20; 59/2008.

\section{REFERENCES}

Anonymus 1957: Vojenská topografická mapa 1:25 000, mapovacie štvorce M-34-121-cd, M-34-121-dc, M-34-121-cc. (The army topographical map 1 : 25 000, map sections M-34-121cd, M-34-121-dc, M-34-121-cc) [in Slovak]. Generální štáb československé armády. Depon. in Ústav krajinnej ekológie SAV, Bratislava.

Barkman, J. J., Doing, H. \& Segal, S. 1964: Kritische Bemerkungen und Vorschläge zur quantitativen Vegetationsanalyse. Acta Bot. Neerl. 13: 394-419.

Biely, A. 1975: Geologická mapa Tribeča 1:50 000 (Geology map of the Tribeč Mts) [in Slovak]. ŠGÚDŠ, Bratislava.
Biely, A. 1996: Vysvetlivky ku geologickej mape Slovenska 1:500 000. (Annotation to the geology map of Slovakia 1:500 000) [in Slovak]. Vydavatel'stvo D. Štúra, Bratislava, 77 pp.

Borhidi, A. 1993: A Magyar flóra szociális magatartás típusai, természetességi és relatív ökológiai értékszámai. (Social behaviour types of the Hungarian flora, its naturalness and relative ecological indicator values) [in Hungarian]. Janus Pannonius Tudományegyetem Növénytani Tanszék, Pécs, 93 pp.

Braun-Blanquet, J. 1964: Pflanzensoziologie. Grundzüge der Vegetationskunde. 3 Aufl. Springer Verlag, Wien, 865 pp.

Dengler, J., Chytrý, M. \& Ewald, J. 2008. Phytosociology. In: Jørgensen, S. E.\& Fath, B. D. (eds): Encyclopedia of ecology. Elsevier, Oxford, pp. 2767-2779.

Dúbravková, D., Chytrý, M., Willner, W., Illyés, E., Janišová, M. \& Kállayné Szerényi, J. 2010: Dry grasslands in the Western Carpathians and the northern Pannonian Basin: a numerical classification. Preslia 82: 165-221.

Eliáš, P. 1986: Vegetácia štátnych prírodných rezervácií Hrdovická a Solčiansky Háj a projektovanej ŠPR Kovarecká dubina (pohorie Tribeč). (Vegetation of nature reserves Hrdlovická, Solčiansky Háj and Kovarecká dubina in the Tribeč Mts.) [in Slovak]. Rosalia 3: $33-79$.

Faško, P. \& Št́astný, P. 2002a: Mapa priemerných ročných úhrnov zrážok, 1:2 000 000. (Map of the average annual precipitation, 1:2 000 000.) [in Slovak]. In: Hrnčiarová, T. (ed.): Atlas krajiny Slovenskej republiky. (The landscape atlas of the Slovak Republic). MŽP SR \& SAŽP, Bratislava, Banská Bystrica, p. 344.

Faško, P. \& Št́astný, P. 2002b: Mapa priemerných úhrnov zrážok v júli, 1:2 000 000. (Map of the average precipitation in July, 1:2 000 000.) [in Slovak]. In: Hrnčiarová, T. (ed.): Atlas krajiny Slovenskej republiky. (The landscape atlas of the Slovak Republic). MŽP SR \& SAŽP, Bratislava, Banská Bystrica, p. 344.

Feráková, V., Maglocký, Š. \& Marhold, K. 2001: Červený zoznam paprad'orastov a semenných rastlín Slovenska. (The red list of ferns and flowering plants of Slovakia.) [in Slovak]. In: Baláž, D., Marhold, K. \& Urban, P. (eds.): Červený zoznam rastlín a živočíchov Slovenska. (The red list of plants and animals of Slovakia.) Ochr. Prír. 20 (Suppl.): 48-81.

Fiala, K. 1999: Záväzné metódy rozborov pôd. 
Čiastkový monitorovací systém - Pôda. (Obligatory methods of the soil analyses. The partial monitoring system - the soil.) [in Slovak]. VÚPOP, Bratislava, $142 \mathrm{pp}$.

Futák, J. 1980: Fytogeografické členenie Slovenska. Mapa 1 : 1000 000. (The phytogeographical division of Slovakia. Map 1:1000 000) [in Slovak]. In: Bertová, L. (ed.): Flóra Slovenska IV/1. (Flora of Slovakia IV/1). Veda, Bratislava.

Geologická mapa Slovenskej republiky, mierka $1: 50000$ (Geological map of the Slovak Republic, $1: 50$ 000) [in Slovak]. ŠGÚDŠ, Bratislava. URL: http://www.geology.sk/index.php?pg=geois.mapovy_server [accessed 2012-01-03].

Hegedüšová, K. 2007: Centrálna databáza fytocenologických zápisov (CDF) na Slovensku [Central database of phytosociological relevés (CDF) in Slovakia]. Bull. Slov. Bot. Spoločn. 29: 124-129.

Hennekens, S. M. \& Schaminée, J. H. J. 2001: TURBOVEG, a comprehensive data base management system for vegetation data. Journal of Vegetation Science 12: 589-591.

Herben, T. \& Münzbergová, Z. 2003: Zpracování geobotanických dat v príkladech. I. Data o druhovém složení. (Analysis of geobotany data in examples. I. Species composition data). Katedra botaniky PřF UK, Praha, 118 pp.

Husová, M. 1967: Azidophile Eichenwälder auf Quarziten im Tribeč-Gebirge, Slowakei. Fol. Geobot. et Phytotax. 2: 121-136.

Húsenica, J. 1964: Minerálna sila materských hornín lesných pôd na Slovensku. (Minerals in the bedrocks of the forest soils in Slovakia) [in Slovak]. Vydavatel'stvo SAV, Bratislava, 246 pp.

Chytrý, M. (ed.) 2007: Vegetace České republiky. 1. Travinná a keříčková vegetace (Vegetation of the Czech Republic. 1. Grassland and heathland vegetation.) [in Czech with English summaries]. Academia, Praha, 526 pp.

Chytrý, M., Hoffmann, A. \& Novák, J. 2007: Suché trávníky (Festuco-Brometea). (Dry grasslands (Festuco-Brometea)). In: Chytrý, M. (ed.): Vegetace České republiky. 1. Travinná a keř́ćcková vegetace (Vegetation of the Czech Republic. 1. Grassland and heathland vegetation.) [in Czech with English summaries]. Academia, Praha, pp. 371-497.

Chytrý, M., Mucina, L., Vicherek, J., PokornyStrudl, M., Strudl, M., Koó, A. J. \& Maglocký,
Š. 1997: Die Pflanzengesellschaften der westpannonischen Zwergstrauchheiden und azidophilen Trockenrasen. Diss. Bot. 277: 1-108. Ivanička, J., Polák, M., Hók, J., Határ, J., Greguš, J., Vozár, J., Nagy, A., Fordinál, K., Pristaš, J., Konečný, V. \& Simon, L. 1998: Geologická mapa Tribeča $1: 50000$. (Geology map of the Tribeč Mts $1: 50$ 000) [in Slovak]. MŽP SR, GÚDŠ, Bratislava.

Ivanička, J., Havrila, M. \& Kohút, M. 2007: Geologiská mapa Považského Inovca a JV časti Trenčianskej kotliny 1:50 000. (Geology map of the Považský Inovec Mts and the SE part of the Trenčianska kotlina Basin 1:50 000) [in Slovak]. MŽP SR, ŠGÚDŠ, Bratislava.

Janišová, M., Hájková, P., Hegedüšová, K., Hrivnák, R., Kliment, J., Michálková, D., Ružičková, H., Řezníčková, M., Škodová, I., Tichý, L., Uhliarová, E., Ujházy, K. \& Zaliberová, M. 2007: Travinnobylinná vegetácia Slovenska elektronický expertný systém na identifikáciu syntaxónov (Grassland vegetation of Slovakia - electronic expert system for identification of syntaxa) [in Slovak with English summaries]. Botanický ústav SAV, Bratislava, 264 pp.

Jarolímek, I. \& Šibík, J. (eds.) 2008: Diagnostic, constant and dominant species of the higher vegetation units of Slovakia. Veda, Bratislava, $332 \mathrm{pp}$.

Korneck, D. 1974: Xerothermvegetation in Rheinland-Pfalz und Nachbargebieten. Schriftenr. Vegetationsk. 7: 1-196.

Lapin M., Faško P., Melo M. \& Štastný P. 2002: Mapa klimatických oblastí, 1 : 1000 000: (Map of the climatic regions, $1: 1000$ 000.) [in Slovak]. In: Hrnčiarová, T. (ed.) Atlas krajiny Slovenskej republiky. (The landscape atlas of the Slovak Republic). MŽP SR \& SAŽP, Bratislava, Banská Bystrica, p. 344.

Marhold, K. \& Hindák, F. (eds.) 1998: Checklist of non-vascular and vascular plants of Slovakia. Veda, Bratislava, 688 pp.

Mederly, P. \& Hreško, J. 1988: Geologický a geomorfologický výskum ŠPR Solčiansky Háj, Hrdovická a Kovarecká hôrka, II. čast'. (Geological and geomorphological study of the Solčiansky Háj National Nature Reserve, Hrdovická and Kovarecká hôrka, $2^{\text {nd }}$ part.) [in Slovak]. Rosalia: 23-46.

Michálková, D. 2007: Koelerio-Phleion phleoidis Korneck 1974. In: Janišová, M., Hájková, P., Hegedüšová, K., Hrivnák, R., Kliment, J., Michálková, D., Ružičková, H., Řezníčková, M., 
Škodová, I., Tichý, L., Uhliarová, E., Ujházy, K. \& Zaliberová, M.: Travinnobylinná vegetácia Slovenska - elektronický expertný systém na identifikáciu syntaxónov. (Grassland vegetation of Slovakia - electronic expert system for identification of syntaxa) [in Slovak with English summary]. Botanický ústav SAV, Bratislava, pp. 86-89.

Palmer, M. W. 1993: Putting things in even better order - the advantages of canonical correspondence analysis. Ecology 74: 2215-2230.

Roleček, J., Tichý, L., Zelený, D. \& Chytrý, M. 2009: Modified TWINSPAN classification in which the hierarchy respects cluster heterogeneity. J. Veg. Sci. 20: 596-602.

Šmarda, P. 2008: DNA ploidy level variability of some fescues (Festuca subg. Festuca, Poaceae) from Central and Southern Europe measured in fresh plants and herbarium specimens. Biologia 63: 349-367.

Št́astný P., Nieplová E. \& Melo M. 2002: Mapa priemernej ročnej teploty vzduchu, $1: 2000$ 000: (Map of the average annual air temperature, 1:1 000 000.) [in Slovak]. In: Hrnčiarová, T. (ed.) Atlas krajiny Slovenskej republiky. (The landscape atlas of the Slovak Republic). MŽP SR \& SAŽP, Bratislava, Banská Bystrica, p. 344.

ter Braak, C. J. F. \& Prentice, I. C. 1988: A theory of gradient analysis. Adv. Ecol. Res. 18: 271317.

ter Braak, C. J. F. \& Šmilauer, P. 2002: CANOCO reference manual and CanoDraw for Windows user's guide. Software for canonical community ordination (version 4.5). Biometris, Wageningen \& České Budějovice, 500 pp.

Tichý, L., 2002: JUICE, software for vegetation classification. Journal of Vegetation Science 13: 451-453.

Westhoff, V. \& van der Maarel, E. 1973: The Braun-Blanquet approach. In: Whittaker, R. H. (ed.): Ordination and classification of communities. Dr. W. Junk Publishers, The Hague, pp. 617-727.

Zlinská, J. 2000: Vegetácia Holubyho lesostepi pri Vinosadoch v Malých Karpatoch. (Vegetation of the Holubiho lesostep near Vinosady in the Malé Karpaty Mts) [in Slovak with English summary]. Acta Envir. Univ. Comenianae 10: 139-152. 